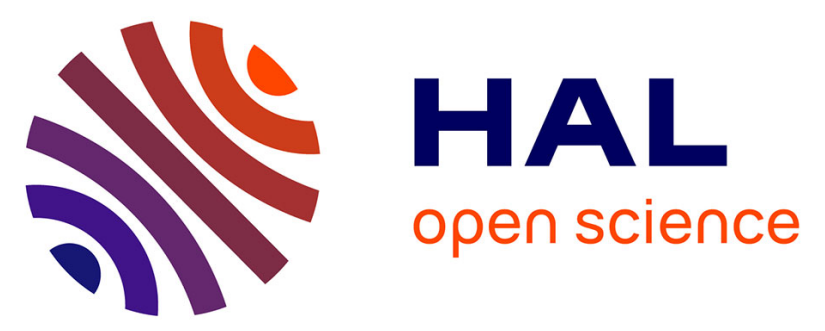

\title{
Discharge and suspended sediment flux estimated along the mainstream of the Amazon and the Madeira Rivers (from in situ and MODIS Satellite Data)
}

Sylvain Mangiarotti, J. M. Martinez, Marie-Paule Bonnet, D. C. Buarque, N. Filizola, Pierre Mazzega Ciamp

\section{To cite this version:}

Sylvain Mangiarotti, J. M. Martinez, Marie-Paule Bonnet, D. C. Buarque, N. Filizola, et al.. Discharge and suspended sediment flux estimated along the mainstream of the Amazon and the Madeira Rivers (from in situ and MODIS Satellite Data). International Journal of Applied Earth Observation and Geoinformation, 2013, 21, pp.341-355. 10.1016/j.jag.2012.07.015 ird-01062703

\section{HAL Id: ird-01062703 https://hal.ird.fr/ird-01062703}

Submitted on 10 Sep 2014

HAL is a multi-disciplinary open access archive for the deposit and dissemination of scientific research documents, whether they are published or not. The documents may come from teaching and research institutions in France or abroad, or from public or private research centers.
L'archive ouverte pluridisciplinaire HAL, est destinée au dépôt et à la diffusion de documents scientifiques de niveau recherche, publiés ou non, émanant des établissements d'enseignement et de recherche français ou étrangers, des laboratoires publics ou privés. 


\title{
Discharge and Suspended Sediment Flux Estimated along the Mainstream of the Amazon and the Madeira Rivers (from in situ and MODIS Satellite Data)
}

\author{
Mangiarotti a, ${ }^{*}$ S., Martinez ${ }^{b, c}$ J.-M., Bonnet ${ }^{b, c}$ M.-P., Buarque ${ }^{d}$ D.C., Filizola e N. \& Mazzega b,c P. \\ a Centre d'Etudes Spatiales de la Biosphère, UPS-CNRS-CNES-IRD, 18 avenue Édouard Belin, 31401 Toulouse, \\ cedex 9, France \\ ${ }^{b}$ Géosciences Environnement Toulouse, UPS-CNRS-IRD-CNES, Observatoire Midi-Pyrénées, 14 avenue Édouard \\ Belin, 31400 Toulouse, France \\ c International Joint Laboratory Observatoire des Changements Environnementaux, Institut de Recherche pour le \\ Développement - Universidade de Brasilia, Campus Universitário Darcy Ribeiro, CEP 70910-900, Brasilia, Brazil \\ a Instituto de Pesquisas Hidráulicas, Universidade Federal do Rio Grande do Sul, Porto Alegre, Brazil \\ e UNMH/Centro de Estudos Superiores do Trópico Úmido - Universidade do Estado da Amazonas e Intituto PIATAM, \\ Av. Darcy Vargas, 1200, S/ C-28, Pq.10 de Novembro, 69000-000 Manaus, AM, Brazil.
}

\section{Abstract:}

Water and suspended sediment fluxes are considered during the period 2000-2008 in a region including the full Amazon River from the confluence of the Negro River to Santarém, the end part of the Solimões River, and the lower part of the Madeira River. Three types of data are used: water discharge estimated from field measurements, and suspended sediment obtained from field measurements and derived from MODIS satellite data. A generalized least square method including a propagating term is developed in order to propagate the signal upward and downward the river. The approach is introduced and tested. Several experiments are considered in order, first, to estimate the ability to propagate the signal from stations located before the confluences of Negro and Madeira Rivers to stations located on the Amazon River; second to investigate the possibility to propagate the signal along the Amazon River which dynamics is coupled with floodplains dynamics; and third to produce optimal solutions of water and sediment fluxes. For each experiment, the influence of field and satellite data is compared. The approach is efficient in the upper part of the region of study where the Solimões, the Negro and the Madeira Rivers meet and fails in the lower part of the region where interactions between Amazon River and floodplains play an important role on the fluxes' dynamics. The optimal experiment includes in situ and satellite data from all the stations available and is used to analyse the recent evolution of suspended sediment flux along the Amazon River and its interaction with the large coupled floodplains. A high accumulation rate is observed during the 2000-2002 period, followed by decreasing rates until 2005 and by increasing values in 2006 and 2007. Our results suggest that floodplains extending along a river reach of $390 \mathrm{~km}$-long between Itacoatiara and Óbidos trap about $15 \%$ of the suspended sediment flux passing at Óbidos. The simulated deposition rate is of about $0.3 \mathrm{Mt} \mathrm{km}^{-1} \mathrm{yr}^{-1}$ corresponding to an accretion rate of about $27 \mathrm{~mm} \cdot \mathrm{yr}^{-1}$.

Keywords: suspended sediments; remote sensing; sediment transport; Amazonian Basin; statistical modelling

\section{Introduction}

As integrated variables, discharge and suspended sediment fluxes of the larger Rivers in the world are important indicators of the large-scale climatic conditions, land uses and climatic changes. However, their dynamics are complex in time and space. Rivers' discharge depends not only on the spatial distribution of rainfalls, but also on many other processes and characteristics including water transfer from watershed to river which depends, itself, on land cover, soils properties, morphology of the

\footnotetext{
*To whom correspondence should be sent : sylvain.mangiarotti@cesbio.cnes.fr
} 
watercourse (slope, depth and rugosity among others), and on interactions between watercourse and flooded areas (Mertes et al. 1995). Similarly, suspended sediment flux relies on the topography and lithology of the drained surfaces, on the size and nature of the eroded particles and on the hydrodynamics of the river (Dunne et al. 1998; Maurice-Bourgoin et al. 2007; Bonnet et al. 2008). To better understand the dynamics of the water and suspended sediment fluxes along rivers, an adequate time and space sampling of the fluxes is required (Calmant \& Seyler 2006; Melack et al. 2004). Unfortunately, hydrological studies have to face the challenge of a decreasing availability of in situ gauges (Fekete \& Vorosmarty 2007) in the world and more particularly in large remote basins such as the Amazon Basin, the River Plate Basin or the Congo Basin. The Amazon Basin is the largest in the world with an area of about 6.1 millions of $\mathrm{km}^{2}$ (Goulding et al. 2003). Its monitoring is particularly difficult, and large regions remain ungauged or poorly understood (Filizola et al. 2009). The Amazon Basin represents about 15\% of the global freshwater input to ocean (Molinier et al. 1996; Callède et al. 2010; see also Richey et al. 1986 for a previous estimate of 20\%) with a mean annual discharge of 209 $000 \mathrm{~m}^{3} / \mathrm{s}$ (Molinier et al. 1996), and plays an important role on global climate regulation (Nobre et al. 2009). The discharge of the Amazon River is directly driven by the regional climatic conditions. It has a mono-modal regime resulting from the integrated contributions of the various tributaries draining contrasted regional climatic regions (Molinier et al. 1996). Its dynamic is also characterized by a large variability in amplitude and phase from one year to another, which is linked to the interannual variations of the climatic control (Marengo et al. 1998). It can be noted that the maximum discharge ever recorded has recently been exceeded during the 2009 flood with a value of about $258900 \mathrm{~m} 3 / \mathrm{s}$ (ORE Hybam) and that several drought events were experienced in the last decades $(2005,2010)$ with minimum discharge of $60000 \mathrm{~m}^{3} / \mathrm{s}$ or less. For practical reason, direct monitoring of discharge and suspended sediment concentration (SSC) can be achieved only at a reduced number of sites, which are generally located at the outlet of large integrator sub-basins (ORE Hybam http://www.ore-hybam.org). Despite such distribution allows establishing water and sediment budget accurately (Martinez et al. 2009), it but should be reinforced to quantify more precisely the inner-processes responsible for the spatiotemporal dynamics of the fluxes and to better understand their responses to climate variability and cover changes in the basin.

The lack of measurements of water level and discharge of the large floodplains connected to the main course of the Amazon River prevents from estimating the part of the Amazon discharge that flows through the large associated floodplains. The fluxes exchanged between mainstream and floodplains are still a subject of debates and the figure depends on the estimation methodology, on the space and time scales under consideration, and on the geographic areas of study. Effectively, contrasted dynamics may be expected when considering the individual lakes water balances (e.g. Lesack \& Melack 1995; Bonnet et al. 2008), the hydraulic dynamics of a $260 \mathrm{~km}$ reach (Wilson et al. 2007), the flood wave routing schemes along a $2000 \mathrm{~km}$ reach (Richey et al. 1989) or the gravity anomalies derived from satellite data for a portion of the central basin (Alsdorf et al. 2010). However, such subsystems are interconnected when considering the whole basin and play an important role on flood and drought damping, and also on suspended matter transport. Due to the interactions taking place between these numerous subsystems, processes at work in the dynamics of sediment fluxes are especially difficult to capture from only few gauges stations. Suspended particles fluxes are influenced by river inner processes (bank erosion, deposition along meanders). Exchanges with the floodplains also play an important role, following a complex cycle of accumulation during the flood rise; export of sediments from floodplains to the mainstream at falling water stage; deposition in the lakes and channels during the high water stage (Meade 1994; Mertes et al. 1995; Maurice-Bourgoin et al. 2007). As a consequence, signal of suspended particles flux is partly decorrelated from the water discharge and no simple relation is found between them (Guyot et al. 2005).

In situ gauge information can be interestingly completed by satellite measurements which provide a higher cover in space with regular sampling in time, although the lengths of record obtainable from such sources are, as yet, fairly short. Satellite altimetry is a powerful tool for measuring water height of large 
rivers (Calmant \& Seyler 2006; Frappart et al. 2006; Santos da Silva et al. 2010). Combined with a simple static or dynamic model, it can provide complementary information about discharge (León et al. 2006; Zakharova et al. 2006). On the other hand, water color measurements can be used to assess SSC at the water surface. MODIS data, based on a multi frequency acquisition in the optic bands, can be used to estimate the surface density of the particles (Kilham \& Roberts 2011; Espinoza et al. in press) and, when combined with in situ data, can also be used to derive the integrated particle content over the depth (Martinez et al. 2009). Using field sampling data and MODIS satellite images, it has been shown that river's sediment discharge can be retrieved with a fine accuracy (Martinez et al. 2009; Espinoza et al. 2012).

To estimate the flows along the main streams, it is necessary to develop robust approaches able to propagate the information in time and space. It is with this intention that a simple statistical method is suggested here. The approach introduced in this paper belongs to the inverse methods and is based on a Generalized Least Square (GLS) method (Tarantola \& Valette 1982), which is now a classical approach in geophysics and oceanography (e.g. see Mangiarotti 2007 for another example of application using satellite altimetry data). By applying this methodology, the target is to estimate the discharge and the suspended sediment flux along the mainstream of the Amazon and the Madeira Rivers together with an error budget. The monitoring of SSC along large rivers such as the Amazon River is an important task that may allow a better understanding of the local scales behaviors along the river and thus, to quantify sediment exchanges with other reservoirs and their transports all along the river with more precision. To do so, the approach should first be developed and tested onto a data network currently available. Two main questions are addressed in this paper: how far can the information of SSC be propagated downstream, and what can be the hydrological causes of information losses. The data used in this paper are described in the next section. Basic statistics applied to extract some characteristics necessary for the methodological development are presented in section 3. The methodology is then given in section 4. Results are described and discussed in section 5, and conclusions are drawn in the last section.

\section{Data}

2.1 Study area and notations

The area of study is presented in Figure 1 associated with its simplified schema that includes five measurement stations (see Table 1 for details). It corresponds to the confluence of three of the Amazon River main tributaries: the Solimões River that drains most of the West Central part of the Amazon basin; the Negro River that drains a significant part in the North hemisphere of the catchment; and the Madeira River that drains the Southern part of the catchment. The scheme also includes five in situ gauge stations namely: Manacapuru, on the Solimões River; Santarém, the most downstream station of the Amazon River; a few kilometres downstream the Óbidos station; the Itacoatiara station located on the Amazon River; and the Borba station located on the Madeira River. Five reaches denoted by 1, 2, 3, 6 and 7 (see Appendix A.1 for notation) are considered in the study during the period 2000-2008. Their lengths $D_{i}$ are given in Table 2. Distances along each reach are denoted by $d_{i}$ and have origin at the downstream endpoint. Total distance computed from Santarém is denoted by $d$. The list of the variables used in the text is also given in Table 2.

$\begin{array}{llll}\text { INSERT } & \text { FIG } & 1 & \text { HERE } \\ \text { INSERT } & \text { TAB } & 1 & \text { HERE } \\ \text { INSERT } & \text { TAB } & 2 & \text { HERE }\end{array}$

\subsection{Data used}

(i) Discharge.

Daily discharges were obtained from Brazilian National Water Agency ANA (Agência National de Águas) at three gauge stations (Manacapuru along the Solimões River, Borba along the Madeira River, and Óbidos along the Amazon River. There are no gauge records available for the lower reach of the Negro River (reach 7). Positions along the reaches are at $d_{1}=70 \mathrm{~km}, d_{2}=160 \mathrm{~km}$ and $d_{3}=92 \mathrm{~km}$, 
respectively, as presented in Table 1). The time series are shown in Figure 2 for the time period 2000 to 2008. Following the precipitation geographic pattern, the flood first comes from the South (Madeira basin), from March to April, followed by the central part of the basin drained by the Solimões River (May to June), while the northern tributaries experience high water period from June to August. The Amazon River that receives all these tributaries has a maximum flood from May to June and low water period from October to December.

(ii) Surface SSC from field measurements

INSERT FIG 2 HERE

In situ surface SSC were downloaded from the ORE HYBAM database for the Manacapuru, Borba and Óbidos stations. Concentrations have a 10-day sampling rate and are determined after filtration of water samples $(500 \mathrm{ml})$ collected near the surface at the middle of the river width on cellulose acetate membranes (porosity of $0.45 \mu \mathrm{m}$ ) pre-weighted and dried after filtration at $115^{\circ} \mathrm{C}$ during 6 hours.

(iii) Surface SSC from satellite data.

Surface SSC data were computed at the same positions of Manacapuru, Borba, Óbidos gauges and at one satellite station: Itacoatiara. The retrieved surface SSC is deduced from a succession of image processing techniques (clustering classification, Monte Carlo sorting and spectral unmixing) for which details are given in Martinez et al. (2009). Both Terra and Aqua MODIS (250-meter and 8-day resolution) composites are considered allowing an uninterrupted time series from 2000 to 2008. While in situ sampling procedure does not permit the investigation of eventual heterogeneities in the River crosssection, satellite-based estimation does.

Average SSC in the cross-section can be assessed from surface SSC, as it was shown in Martinez et al. (2009), using relationships derived from sampling campaigns. During theses campaigns SSC are determined at several depths and locations along the cross-section enabling to establish a relationship with the surface concentration. For all the stations we found a linear regression that could be used to transform surface concentration (in situ or satellite-based) in average concentration. Time series for the in situ and satellite-based SSC are shown in Figure 3.

INSERT FIG 3 HERE

\subsection{Data pre-processing}

(i) Discharge.

The climatologic discharge $\phi_{\text {clim }}(t)$ was obtained by averaging each day of each available year of data from the complete data set for the 1995-2007 period. The climatologic discharge estimated at Manacapuru, Borba and Óbidos as well as their inter-annual variability are presented in Figure 4 . The magnitude and the amplitude of the signal are much higher at Óbidos (see Table 3) than at upstream stations. The initial data distribution is clearly not Gaussian: an almost uniform distribution at Óbidos is found while distributions are clearly asymmetric at Borba and Manacapuru. After the averaged intraannual year is removed, the residual distribution becomes visually closer to a Gaussian distribution (Figure 4) which is a pre-requisite condition for the application of the GLS method (see Tarantola \& Valette 1982).

INSERT TAB 3 HERE

(ii) Suspended Sediment concentration.

In a similar way, the climatologic SSC $\varphi_{\text {clim }}(t)$ was derived at the 3 satellite stations located at Manacapuru, Borba and Óbidos (Figure 5). The inter-annual variability of SSC is also plotted. The higher concentration and the larger amplitudes are observed at Borba station (see Table 3) because the Madeira basin drains the Bolivian Andean, a region richer in erosive material. Initially, the distribution of the data is visually clearly not Gaussian (non symmetric distribution) and becomes more Gaussian after the intra-annual year value is removed. 


\section{Method}

The methodology developed here aims at estimating the discharge $\varphi_{i}(t, x)$ and the suspended sediment flux $\phi_{i}(t, x)$ along reaches $i=1,2,3$ and 6 by propagating the information along the watercourse. Three main tributaries of the Amazon River (the Solimões River, the Madeira River and the Negro River) are considered in this study (see Figure 1). The SSC $\rho_{i}(t, x)$ in $\mathrm{g} \mathrm{m}^{-3}$ (or mg l-1) along reach $i$ can be estimated locally at time $t$ and distance $x$ by the following relation:

$\rho_{i}(t, x)=\frac{\phi_{i}(t, x)}{\varphi_{i}(t, x)}$

where $\varphi_{i}(t, x)$ denotes the discharge (in $\mathrm{m}^{3} \mathrm{~s}^{-1}$ ) and $\phi_{i}(t, x)$ denotes the suspended sediment flux (in $\mathrm{g} \mathrm{s}^{-1}$ ) assuming that propagation averaged velocity is identical for both water and suspended sediments.

\subsection{The general least square method}

The GLS method aims to estimate unknown parameters based on a linear regression model taking into account the spatiotemporal characteristic of the data and its associated error budget. Its application implies a relative degree of correlation in the observed behavior. The GLS method requires to set an a priori model, and to define a covariance function (including its parameterization). It also requires observed data as inputs. In the present work, the GLS method is used to estimate the discharge and the SSC in both space (along the river) and time. A priori information is required in such approach. The a priori model $\varphi_{i}^{0}(t, x)$ was chosen as follows:

$\varphi_{i}^{0}(t, x)=\left(1+\alpha_{\varphi} x\right) \cdot \varphi_{\text {clim }}(t \bmod [1$ year $]) \quad \forall t$

for the discharge, where $\varphi_{\text {clim }}$ is the climatologic discharge (as computed in section 2.3), $\alpha_{\varphi}$ is the along stream amplification coefficient of the flow accounting for the lateral fluxes resulting from floodplains and basin surfaces (a negative value corresponds to a loss, a positive value to a gain) and where $t \bmod [1$ year] represents the yearly repetitiveness of the climatologic model. Another a priori model $\rho_{i}^{0}(t, x)$ is chosen as:

$\rho_{i}^{0}(t, x)=\rho_{\text {clim }}(t \bmod [1$ year $]) \quad \forall t$

for the SSC, where $\rho_{\text {clim }}$ is the climatologic SSC (computed as explained in section 2.3). As an a priori model, a climatologic year is preferred rather than a constant value: firstly because the a posteriori model will approach the climatic cycle when no data is available (which is more realistic than a constant); secondly because the distribution of the data around the climatic cycle will thus be closer to a Gaussian distribution (see Figure 4 and 5) which is a background hypothetic condition for the applicability of the GLS method.

The covariance error matrix is an important part of the GLS method and must be defined cautiously. Due to the poor information available about the distribution of the information when the signal propagates, a Gaussian distribution can reasonably be assumed and a propagation term has been 
included. One covariance function $C(\delta t, \delta x)$ has been chosen for this purpose. The function $C(\delta t, \delta x)$ represents the correlation / decorrelation of the propagated signal and is defined as follows:

$C(\delta t, \delta x)=\sigma^{2} e^{-\frac{\left(\delta t-\frac{\delta x}{c}\right)^{2}}{2 \Delta_{t}^{2}}} e^{-\frac{(\delta x)^{2}}{2 \Delta_{r}^{2}}}$

where $\sigma$ is the characteristic variance of the signal; $\Delta_{t}$ and $\Delta_{r}$ are the time and space decorrelation, respectively; $\delta t$ is the temporal distance and $\delta x$ the spatial distance (along the reach) between the time when (respectively the locations where) the simulated and observed values take place; $c$ is the velocity which is assumed to be constant, here. A covariance function $B(\delta t, \delta x)$ accounting for the uncorrelated noise is also introduced. It is defined as:

$$
B(\delta t, \delta x)=\sigma_{0}^{2} \cdot \delta_{k l} \quad \text { with } \quad \delta_{k l}=1 \quad \text { if } \quad \delta t=\delta x=0
$$

where $\sigma_{0}$ is the variance of the uncorrelated noise (in time and space). The same shape of the covariance function and covariance error are used for all reaches and for both discharge and SSC estimates. However, different coefficients $\sigma, \Delta_{t}, \Delta_{r}$ and $\sigma_{0}$ are chosen from one reach to another (see section 3.5). The a posteriori discharge $\hat{\varphi}_{i}(t, x)$ and SSC $\hat{\rho}_{i}(t, x)$ can thus be directly calculated from the GLS method (see Appendix A.2).

\subsection{Relations at the reach confluence}

The total mass conservation for the discharges at the confluence between reach $i$ and the upstream reaches $2 i$ and $2 i+1$ is expressed as follows:

$$
\phi_{i}\left(t, D_{i}\right)=\phi_{2 i}(t, 0)+\phi_{2 i+1}(t, 0)
$$

where $D_{i}$ is the length of the reach $i$. Similarly, the suspended sediment flux can be expressed at the confluence between reaches $i, 2 i$ and $2 i+1$ as:

$$
\varphi_{i}\left(t, D_{i}\right)=\varphi_{2 i}(t, 0)+\varphi_{2 i+1}(t, 0)
$$

A relation for the SSC concentration can be deduced from Eq. 1, 6 and 7 and written as:

$$
\rho_{i}\left(t, D_{i}\right)=\frac{\rho_{2 i}(t, 0) \cdot \varphi_{2 i}(t, 0)+\rho_{2 i+1}(t, 0) \cdot \varphi_{2 i+1}(t, 0)}{\varphi_{i}\left(t, D_{i}\right)}
$$

\subsection{Computation steps}

As mentioned in section 2.1, the Negro's discharge at the confluence with the Solimões River is not available. Therefore, the following steps are applied: (a) the discharge is firstly estimated with the GLS method along reaches 1, 2 and 6, based on the information provided by Óbidos, Borba and Manacapuru stations, respectively; (b) Using Eq. 6 , the outflow of reach 3 is deduced from the outflow of reach 2 together with the inflow of reach 1; (c) The discharge is then estimated with the GLS method along reach 3 based on the outflow. SSC of reach 7 is assumed to be negligible compared with the concentration observed along the other reaches (actually SSC of the Negro River is less than $2 \mathrm{mg}^{-1} \mathrm{I}^{-1}$, Sioli 1984). Therefore, the conservation relation given in Eq. 8 becomes, for $i=3$ : 
$\hat{\rho}_{3}\left(t, D_{3}\right)=\frac{\hat{\rho}_{6}(t, 0) \cdot \hat{\varphi}_{6}(t, 0)}{\hat{\varphi}_{3}\left(t, D_{3}\right)}$

The propagation can thus always be applied following the stream direction according to the following steps: (a) The SSC is estimated with the GLS method along reach 6; (b) $\hat{\rho}_{3}\left(t, D_{3}\right)$ is deduced from Eq. 9; (c) from this information, SSC is estimated with the GLS method along reach 3; (d) SSC is then estimated with the GLS method along reach 2; (e) Equation (8) is used with $i=1$ to calculate $\hat{\rho}_{1}\left(t, D_{1}\right)$; (f) The SSC is thus estimated with the GLS method along reach 1 using satellite and/or in situ stations (several experiments are tested, see section 3.5). Once both the discharge and the SSC have been estimated along all the reaches, the suspended sediment flux can be deduced locally from Eq. 1 together with the error budget.

\subsection{Parameters}

Five parameters (i.e. $\sigma, \sigma_{0}, \Delta_{t}, \Delta_{x}$ and $c$ ) of the covariance function (Eq. 4) and covariance error (Eq. 5) have to be set for each variable (discharge and SSC) and for each reach. These parameters are the following:

(1) $\sigma$ represents the variance of the signals $\phi(x, t)$ and $\rho(x, t)$ to be extracted and propagated. The dispersion of the variables exhibiting a seasonal behaviour, it was chosen to take into account this seasonality explicitly in the correlation function. Indeed, $\sigma$ can vary in time with a seasonal variability assumed. $\sigma(t)$ is estimated from the dispersion of the climatologic year (see figures 4 and 5 for discharge and SSC, respectively) and can be expressed as follows:

$\sigma_{i}^{\varphi}(t, x)=\sigma_{i}^{\varphi_{\text {dim }}}(t \bmod [1$ year $]) \quad \forall t$

and:

$$
\sigma_{i}^{\phi}(t, x)=\sigma_{i}^{\phi_{\text {dim }}}(t \bmod [1 \text { year }]) \quad \forall t
$$

where $i$ is the reach number.

(2) $\sigma_{0}$ represents the variance of the uncorrelated noise. It is assumed to be constant in time and is estimated empirically in order to stabilize the matrix inversion.

INSERT TAB 4 HERE

(3) $c$ is the propagation velocity. It is assumed to be constant in time, uniform in space and identical for both water and suspended sediments (however, it can vary from one reach to another). To estimate this velocity, the correlation of the signal of discharge between Óbidos and Manacapuru is estimated with a time delay $\delta t$ ranging from 0 to 20 days. The same correlation analysis is applied to the signal of SSC (see Table 4), and can also be applied between Borba and Óbidos (see Table 5); for this latter case, the contribution of Manacapuru must be removed from Óbidos station. The time corresponding to the higher correlation should lead to a more realistic propagation time. When directly applied to the original signal, this methodology may lead to erroneous estimates due to the geographical phasing resulting from the climatic controls or due to high frequency perturbations or noise. Indeed, to estimate velocity with a good precision, high correlation values are expected to correspond to a narrow range of time delay. A satisfying trade off between correlation and precision should be obtained. A filtering was thus applied to the signal before estimating the correlation: this filtering was performed by transforming the signal into the frequency domain thanks to a Fast Fourier Transform (FFT); a band of frequency defined by a lower and a higher frequency was thus extracted; and an inverse FFT was applied to this band to come back to the time domain. Bands of various size were thus applied (e.g. Figure 6), from which a time range (and celerity range) was deduced corresponding to $95 \%$ of the 
maximum correlation (see Tables 4 and 5). The estimates resulting from the 50 to 150 days band filtering lead to a more relevant results (corresponding to case 4 in Figure 6), with both a high correlation level and a narrower band of celerity. Between Óbidos and Manacapuru, note that the higher correlations are obtained with the signal of discharge (perturbations by the Madeira River being small). On the opposite, since the Madeira River has a very high SSC, the higher correlations between Borba and Óbidos are obtained with the signal of SSC. The values of $c$ used for each reach are given in Table 6.

INSERT TAB 5 HERE

INSERT FIG 6 HERE

(4) The decorrelation time $\Delta_{t}$ is estimated from the autocorrelation analysis of the time series for both discharge and SSC, and at each of the three stations Óbidos, Borba and Manacapuru (see Table 7). The seasonal component of the signal tends to bias the estimation of the signal autocorrelation. This effect can be bypassed by applying a high pass filter. Decorrelation times obtained after filtering the low frequencies using a high pass filter (<100 days) are presented in Table 7.

INSERT TAB 6 HERE

INSERT TAB 7 HERE follows:

(5) The along stream decorrelation distance $\Delta_{r}$ is assumed to be Gaussian and is computed as

$\Delta_{r}=\sqrt{-\frac{d_{i j}^{2}}{2 \ln \left(r_{i j}\right)}}$

where $d_{i j}^{2}$ is the distance between sections $i$ and $j$ and $r_{i j}$ the correlation between the series $i$ and $j$. The same relation is used for both discharge and SSC signals, with $d_{i j}=562 \mathrm{~km}$ between Manacapuru and Óbidos, and $d_{i j}=630 \mathrm{~km}$ between Borba and Óbidos. Estimates of the correlation distance are given in Tables 4 and 5 . The parameters are considered reach by reach as far as dataset made their evaluation possible. The values of parameters $\Delta_{t}$ and $\Delta_{r}$ used in the general least square method are all given in Table 6.

\subsection{Experiments}

All the experiments are based on the same discharge estimate following the steps defined in section 3.3. The SSC and the suspended sediment flux are then estimated. Three main experiments are considered (experimental inputs are resumed in Table 8):

(1) The first series of experiments aims at quantifying the ability of the method to propagate the signal of SSC and fluxes from upper stations (Manacapuru and Borba), to lower stations Itacoatiara and Óbidos. Three sub cases are considered according to the dataset used as input: (1a) only satellite estimates; (1b) only in situ measurements; and (1c) both satellite estimates and in situ measurements.

(2) The second experiment aims at analysing the signal propagation along reach 1 between Itacoatiara and Óbidos. It is the same as sub experiment (1a) but SSC and resulting suspended sediment fluxes at the Itacoatiara satellite station are also introduced as an input in the inversion. Results simulated at Óbidos are compared with real observations.

(3) The last couple of experiments aim at estimating the ability of the satellite data to complete the in situ measurements and at producing an optimal reconstruction of the SSC and suspended sediment flux along the stream. Therefore, in (3a) only satellite data are used (the efficacy of the satellite data is compared at Manacapuru, Borba and Óbidos where field data are available) whereas in (3b), all satellite estimates and in situ measurements are used in order to obtain an 'optimal' solution.

INSERT TAB 8 HERE

For each of these experiments, results are tested at the Itacoatiara and Óbidos stations. Three efficacy estimators are built based on the distance $J$ between the model output and the satellite 
(superscript S) or in situ (superscript $F$, when available) observations. The performance of the approach is estimated for each of the experiments through the following estimator:

$$
J_{\text {station }}^{S \text { or } F}=\sqrt{\frac{1}{N} \sum_{i=1}^{N}\left(\hat{\varphi}\left(t_{i}, D_{\text {station }}\right)-\varphi_{\text {station }}^{S \text { or } F}\left(t_{i}\right)\right)^{2}}
$$

The resulting estimators $J_{\text {Itacoatiara }}^{S}, J_{\text {Obidos }}^{S}$ and $J_{\text {Obidos }}^{F}$ are reported in Table 8.

\section{Results and discussion}

\subsection{Discharge}

Outputs (discharge and associated error) of the GLS method are shown in Figure 7 for reach 2 (top panels) and successive reaches 6, 3 and 1 together (bottom panels) during the period 2004-2008. The characteristic propagation time between Manacapuru and Óbidos is a few days. The signal is dominated by the intra-annual signal. The inter-annual variability also clearly appears (e.g. higher values in 2006). Error bars are low close to the input stations and increased when far from these; the high error level obtained in reach 3 is due to the lack of information about the discharge of the Negro River. In 2007, the high level of error obtained in reach 6 arises from a lack of data, the model then converges to the climatic a priori model and the error bars become maximum.

\section{INSERT FIG 7 HERE}

\subsection{SSC for the three experiments}

The following question is firstly addressed: does the information from Manacapuru and Borba reach Itacoatiara and Óbidos?

Figure 8 shows the agreement between the GLS model and the observations from the satellite data at Itacoatiara (top plot) and Obidos (bottom plot) stations. Table 8 summarizes the comparisons in the retrieval performance of the different experiments against the field-derived or satellite-derived SSC at Itacoatiara and Obidos stations. The comparison between the a priori model and the results obtained at Itacoatiara from experiments (1-2) is shown in Figure 8 (top plot). The comparison between experiments $(1 \mathrm{a}, 1 \mathrm{~b}, 1 \mathrm{c})$ and the a priori model shows that the SSC estimate is clearly improved by the upstream signal. Results from experiment (2), are also plotted in Figure 8 (top plot) for comparison since it represents an optimal solution. It is clearly observed that a part of the information from Manacapuru and Borba reaches Itacoatiara, even if part of the signal is lost. This might be explained by the relatively low ratio between the maximal inundation area to the reach lengths.

\section{INSERT FIG 8 HERE}

Results obtained in experiments (1a), (1b) and (1c) are overall similar (Table 8 and Figure 8). However, some differences can be noted: better results are obtained with the satellite data only (experiment 1a) which can be explained by a better coherency of the measurements source. When both satellite and in situ measurements are used together, an intermediate result is obtained. The integration of upstream information brings limited but still significant improvements to the GLS performance. It seems that the upstream information is not fully preserved downstream. Several causes may contribute to explain the information loss: the lack of information about the discharge coming mainly from the Negro River or from smaller tributaries, as well as the discharge transiting through the floodplain. Sedimentation and particles re-suspension processes occurring mainly in the large Amazon floodplain system, which are not taken into account locally but only statistically through the correlation functions of the GLS method (see equation 4 which parameters are provided Table 6), may also contribute to the information loss.

At Óbidos, it is also observed that a part of the upstream information coming from Manacapuru and Borba is poorly transferred (see the comparison between experiments (1) and a priori model shown in the bottom plot of Figure 8. Moreover, information added at Itacoatiara station is also poorly 
transferred to Óbidos. Results from experiment (2) are thus only marginally improved compared to experiments (1). This may be explained by the complex behaviour of the dynamics between Itacoatiara and Óbidos where the discharge and suspended sediment flux dynamics are coupled with the dynamics of the large floodplains associated with this part of the Amazon River. In this reach, the ratio of the maximal inundation area to the reach lengths is significantly higher (about $43 \mathrm{~km}^{2} \cdot \mathrm{km}^{-1}$, that is twice the value estimated from Melack \& Hess (2010) between Manacapuru and Itacoatiara and between Borba and Itacoatiara). All year long, water fluxes are transiting through the floodplains with a propagation velocity much weaker than in the main course, and with an alternatively positive or negative floodplain water net balance during the hydrological cycle (Bonnet et al. 2008). The influence of floodplains on suspended sediment fluxes is even more complex. As shown in Maurice-Bourgoin et al. (2007), these vast flooded areas act alternately as a sink and a source of suspended sediment for the main course during the hydrological cycle, but exportation flux from floodplains is strongly impacted by re-suspension events. Therefore, a large part of the dynamics of water and suspended sediment fluxes cannot be transferred through a simple linear propagation model. However, our target here is not to take into account all these effects, but to try to investigate how a simple approach can be used to model our knowledge of the system.

The second question addressed by the conducted experiments concerns the ability of satellite measurements: can satellite information be used to complete or to replace in situ measurements?

When all satellite stations are used (experiment $3 a$ ), the efficiency of the method is provided in Tables 8 . The ability of satellite data to replace in situ measurements does not appear very clearly in our study. Indeed, statistically, the results obtained with satellite data only marginally improve the estimates when compared with the a priori model (Table 8). However, considering the results more carefully, it can be noted that most of the high values of SSC obtained from satellite measurements are improved compared to the a priori model (Figure 9b). In other words, this means that the inversion of the satellite data is mainly efficient for completing the higher values of in situ measurements whereas low values do not bring much information.

This result does not mean that satellite-based estimation of SSC is not useful. Even if the in situ data can bring direct information about field reality, their representativeness must be considered with caution. Indeed, even if a precise protocol is applied for sampling the water, the factual representativeness necessarily depends on the homogeneity of the water. Therefore, SSC can highly vary in space and time. Contrarily, satellite measurements have a space integrated meaning, at least in surface, that may smooth the representativeness variability. Once calibration on in situ measurements is achieved, satellite-based estimation is also the only way to follow the SSC annual variation in some regions of the Amazon basin or elsewhere in the world (Martinez et al. 2009). This result shows that satellite will especially be useful in regions of the Amazon Basin where satellite measurement is the only way to monitor the annual variation of SSC. Therefore, in situ and satellite data can be considered as complementary information and may be advantageously combined in a joint analysis. It is what is done in experiment (3b) which efficacy is shown in Figure 9 and Table 8, leading to an 'optimal' solution for the SSC.

INSERT FIG 9 HERE

\subsection{Suspended sediment flux}

Suspended sediment fluxes analysed in this last paragraph is based on the discharge and SSC obtained from the 'optimal' experiment (3b). Suspended sediment flux and associated error are deduced from Eq. (1) and shown in Figure 10. The upstream/downstream delay caused by the propagation does not visually appear in the pattern due to the large period considered in the illustration (8 years) compared to the propagation time delay of few days. The non-homogeneous behaviour observed along the stream in reach 1 can reasonably be attributed to the suspended sediment outflow from the stream to the floodplain present along the main stream.

INSERT FIG 10 HERE 
It is found that much of the signal observed at Itacoatiara is lost before reaching Óbidos. This does not prevent us from analysing the difference estimated between these two stations, especially if using the 'optimal' solution provided by the joint analysis of in situ and satellite data. The deposition rate expressed in $\mathrm{Mt}^{\mathrm{km}} \mathrm{km}^{-1}$.yr-1 obtained by subtracting the suspended sediment flux passing at Itacoatiara from the suspended sediment flux passing at Óbidos is between 0.15 and 0.41 (Figure 11, top panel). This deposition rate increases from 2000 to 2001, decreases from 2002, reach a minimum in 2005 and increases again in 2006 and 2007 . With one year delay, this trend compares relatively well related to the observed minimum discharge at the Óbidos location (Figure 2, bottom panel): lower is the minimum discharge higher is the deposition rate in the floodplain. This could be the result of the re-suspension processes in floodplain from which higher re-suspension is expected when the minimum discharge is lower. This observation, which needs however to be confirmed using a longer data series, is coherent with stronger re-suspension events observed in floodplains during drought years. As mentioned in Maurice-Bourgoin et al. (2007), deposition in the floodplain occurred during high water stage, but part of the sediments are re-mobilized during the falling and low water periods under the effect of resuspension. During drought year, depth in floodplain is lower and the inundation recession quicker.

INSERT FIG 11 HERE

INSERT TAB 9 HERE

About $15.4 \%$ of the suspended sediment flux passing at the Óbidos location (which is $810 \mathrm{Mt}_{\text {.yr-1 }}$ on average for this period of study) is estimated to be trapped along the reach Itacoatiara-Óbidos with an important year to year variability ranging from $7 \%(2005)$ to $20 \%$ (2002). To make these estimates comparable to previously published values, it is necessary to consider a quantity independent from the spatial scale. Three variables are usually considered to characterize sediment deposition. 1) already mentioned, the deposition rate along the reach corresponding to the mass of sediment accumulated per kilometer and per year; 2) the deposition rate in the floodplain corresponding to the mass of sediment accumulated per square kilometer of floodplain and per year; and 3) the accumulation rate corresponding to the height of sediments accumulated in the floodplain per year. Since a variable can be preferred to another in each study, it is necessary to apply conversions between these variables to be able to compare the results. Comparative values are presented in Table 9 (values taken from the quoted references are highlighted in bold character, others are calculated here for comparison). In the present study, the mean deposition rate along the reach Itacoatiara-Óbidos is estimated to be 0.32

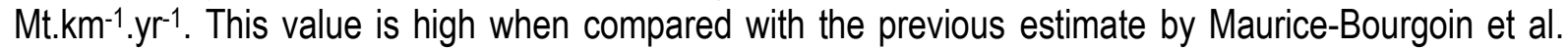
(2007), which was obtained at the local scale of the Curuai floodplain located at the right bank of the Amazon River, in front of Óbidos. Curuaí floodplain is a $120 \mathrm{~km}$-long floodplain segment, and has a maximum flooded area of $2500 \mathrm{~km}^{2}$ with a median value of $1300 \mathrm{~km}^{2}$ (Bonnet et al. 2008). MauriceBourgoin et al. (2007) found that the sediment amount trapped in this floodplain was $0.07 \%$ of the flux

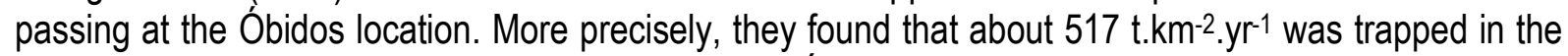
floodplain, whereas the suspended sediment flux at Óbidos was about $964 \mathrm{Mt}_{\mathrm{yr}} \mathrm{r}^{-1}$, leading to a trapped

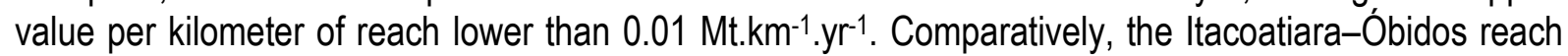
is $390 \mathrm{~km}$-long, maximum and minimum flooded areas are estimated to be $14230 \mathrm{~km}^{2}$ and $2600 \mathrm{~km}^{2}$, respectively (Martinez \& Le Toan 2007). Nonetheless, spatial scale may not explain such a difference in magnitude. Indeed, the sediment accumulation in the Curuaí floodplain was also estimated at the centennial time scale, based on isotopic measurements of $210 \mathrm{~Pb}$ (Moreira-Turcq et al. 2004) leading to accumulation rates ranging between 4.2 and $13.4 \mathrm{~mm}$.yr-1. Assuming a sediment porosity of $75 \%$ and a sediment density of $1.3 \mathrm{~g} . \mathrm{cm}^{-3}$ (Maurice-Bourgoin et al. 2007), these accumulation rates can be converted into a deposition rate along the reach ranging from 0.29 to $0.91 \mathrm{Mt}^{\mathrm{km}} \mathrm{km}^{-1}$. $\mathrm{yr}^{-1}$. Although estimated at different time and space scales, this range of deposition rate is in very good coherency with

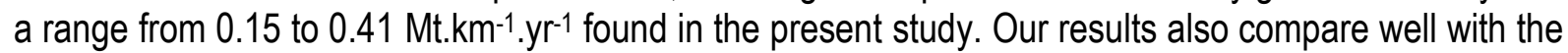
estimates of sediment deposition rates published by Dunne et al. (1998). Deposition rates estimated by these authors range from 0.12 to $0.22{\mathrm{Mt} . \mathrm{km}^{-1} . \mathrm{yr}}^{-1}$ for reaches located between Manacapuru and

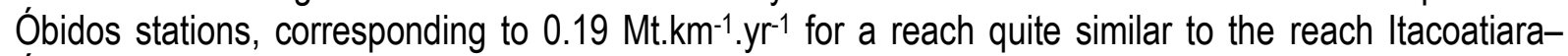
Óbidos considered here. This agreement appears even clearer when considering the deposition rate in 
the floodplain $\left(7.8 \times 10^{3} \mathrm{t}_{\mathrm{km}} \mathrm{km}^{-2} \mathrm{yr} \mathrm{r}^{-1}\right.$ compared to $8.8 \times 10^{3} \mathrm{t} . \mathrm{km}^{-2} . \mathrm{yr} \mathrm{r}^{-1}$ here $)$ and the accumulation rates (24 mm.yr-1 compared to $27 \mathrm{~mm} . \mathrm{yr}^{-1}$ ). These differences in magnitude are very likely to arise from the interannual variability of the dynamics. Quite larger values of deposition rates along the reach (from 1.1

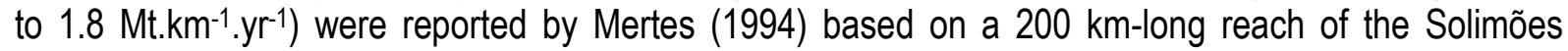
River. However, these values were deduced from measurements performed on the bordering part of the floodplains where deposition rate is known to be higher. When considering measurements performed into the floodplain at location distant $100 \mathrm{~m}$ from the main stream, estimates become much smaller (0.11 Mt.km-1.yr-1 - also provided in Mertes 1994 - leading to a deposition rate in the floodplains of

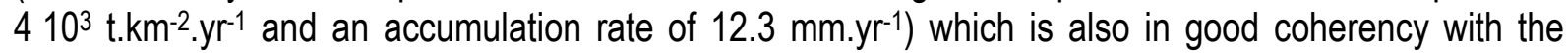
present estimates. At the whole Amazon basin scale, a comparison based on accumulation rates or deposition rates in floodplain may appear more relevant than along the reaches since it will avoid the averaging effects resulting from differentiated flooding areas at larger spatial scale (the ratio between the maximal inundation area to the reach lengths is significantly higher along the reach Itacoatiara-

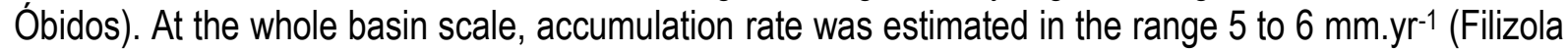
\& Guyot, 2009) which is quite lower than the present estimate of $27 \mathrm{~mm} . \mathrm{yr}^{-1}$. This discrepancy is likely to arise from geographically differentiated behaviors or from scale-dependent behaviors.

Deposition and accumulation rates estimated in the present study are coherent in magnitude with most of the previous studies. Discrepancies are quite small when comparing similar areas of study. Larger differences observed when comparing other results probably result from the time periods and the spatial scales. These discrepancies reflect the difference of behaviors occurring along the stream and illustrate the necessity to intensify the network in order to better capture the spatially differentiated dynamics, and to quantify the suspended sediment flux at more local scale. It also reflects the usefulness of applying a methodology coherent in space, all along the reaches. Such intensified monitoring would certainly permit to improve our knowledge of the processes acting along the river and in the floodplains from local to regional scales.

\section{Conclusions}

A generalized least square method is developed in order to propagate the signal of water discharge and Suspended Sediment flux along the rivers. The approach is applied reach by reach in the Amazonian River basin, in a region located between Manacapuru and Santarém, taking into account the contributions of the Negro and the Madeira Rivers by applying a conservation law at rivers confluences. Several experiments have been tested in order to evaluate the efficiency of the method and its efficacy to propagate the signal from upper stations to lower stations. It is shown that the signal can be efficiently propagated from the stations located before the confluence of Negro, Madeira and Solimões Rivers to the first station located after these confluences. However, the propagation cannot be applied efficiently farther in the lower part of the Amazon River. This difficulty is likely to be due to the complex connections between the Amazon River and its large floodplains. Indeed, connections to floodplains give rise to a complex dynamics that cannot be modelled using a simple signal propagation approach. This result suggests that the density of the measurements sites should be absolutely increased along the river to allow a better understanding of the interaction between river and floodplains and of the contribution of smaller tributaries.

Among the various experiments tested, in situ and satellite data were used together and separately as input of the generalized least square method showing that better results are obtained when coherent sources are used as input and validating data. In fact, in practice, these two data sources present very different advantages and are very complementary. Indeed, Despite field measurements obviously provide a direct estimate of the SSC, its spatial representativeness remain low. Contrarily, although indirect and mostly accounting for the SSC only at the upper river's surface, satellite data provide spatially distributed information with a density in space and time that cannot be obtained from field measurements. Such complementarity strongly promotes the development and usage of joint analysis 
approaches in order to obtain optimal solutions able to appropriately mix in situ and satellite data in association with an error budget. It also promotes the development of methods dedicated to fully satellite-based estimates of SSC in order to densify the measurements network and to dispose information in retired areas with good time space sampling.

An estimate of the Suspended Sediment flux is also driven by applying such a joint analysis of the full data set (in situ and satellite data), aiming to get an optimal view of the Suspended Sediment dynamics. However, these simulations could not allow for a detailed analysis of the local behaviours due to the lack of data well spatially distributed in a context of low spatial correlation of the SSC signal, a situation for which the present approach is not able to compensate. Higher density coverage by satellite data would improve significantly the results and would allow understanding the behaviours occurring along the reaches at a shorter space scales. Our results also suggest that the present approach may be an efficient tool for propagating the signal over a large range of distances (up to 100-150 km) when interaction with floodplains is low enough. Therefore, such an approach may also be a useful tool for modellers when applied forecasting is attempted, for which data assimilation may require an efficient time space interpolator.

Although short scales behaviours cannot be considered at this step, the overall effect of the floodplains contributing between Itacoatiara and Óbidos could be analysed based on optimal solution combining in situ and satellite data sets. Floodplain in the Itacoatiara-Óbidos reach traps about $15 \%$ of the annual suspended sediment flux passing at Óbidos corresponding to a deposition rate of 0.32

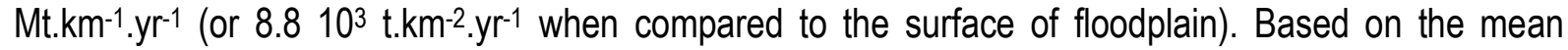
floodplain surface and on the sediment characteristics (density and porosity), the sediment accretion rate is estimated at $27 \mathrm{~mm} . \mathrm{yr}^{-1}$.

\section{Acknowledgements:}

The first author is grateful to the IRD (Institut de Recherche pour le Développement) for founding the mission coast of this collaborative work. This study was also funded by the research project SAMSAT of the French space agency CNES (Centre National d'Etudes Spatiales), the INSU/Relief, the INSU/SYSTER and the RTRA/STAE CYMENT programs. This work was performed within the framework of the ORE Hybam program of IRD and CNPq project $n^{\circ} 490755 / 2008-9$ which permitted the development of the research program in Brazil. We are also grateful to the ANA (Brazilia Water Agency) and the CPRM (Serviço Geologico do Brasil) for providing support for the field trips and access to the hydrological data.

\section{Appendix}

\section{A.1 Notations}

The following notation has been used. It allows for a non-ambiguous description of each reach of the river when the river flow does not separate in several concurrent flows and when two tributaries maximum contribute together to the resulting stream. One reach $i$ has to result from two tributaries, the first one (the right contribution when following the current) is referred as $2 i$, the second one (the left contribution) is referred as $2 i+1$. Converting these numbers to binary directly gives the path from the reference departure. In the present case the binary construction is initiated as 1 on the reach including Santarém (Óbidos and Itacoatiara also, see Figure 1); giving rise to binary notation 10 (reach 2) on the Madeira River; and to 11 (reach 3) between the confluence of the Negro and the Madeira Rivers; then to 110 (reach 6) corresponding to the Solimões River (that includes the Manacapuru station); and 111 (reach 7) corresponding to the Negro River.

\section{A.2 GLS method}


The output $\psi(x, t)$ of the GLS method, representing $\varphi(x, t)$ or $\rho(x, t)$, is obtained from the following equation:

$$
\hat{\psi}(x, t)=\psi^{0}(x, t)+\sum_{i} \sum_{j} C\left(x, x^{k}, t, t^{k}\right) \cdot\left(S^{-1}\right)^{k l} \cdot\left[d_{0}^{l}-\psi_{0}\left(t^{l}\right)\right]
$$

where $\psi^{0}(x, t)$ is the model a priori, $C$ is the covariance matrix resulting from the covariance function (see eq. 4 and 5), $d_{0}^{l}$ denotes the data series and where $S^{k l}$ is as follows:

$$
S^{k l}=\left(C_{d_{0} d_{0}}\right)^{k l}+B\left(\delta t^{k l}, \delta x^{k l}\right)+C\left(\delta t^{k l}, \delta x^{k l}\right)
$$

with $\left(C_{d_{0} d_{0}}\right)^{k l}$ the diagonal matrix of the data error $\sigma_{l}^{2}$ associated with $d_{0}^{l}$.

The a posteriori covariance error reads:

$$
\hat{C}\left(x, x^{\prime}, t, t^{\prime}\right)=C\left(x, x^{\prime}, t, t^{\prime}\right)-\sum_{i} \sum_{i} C\left(x, x^{k}, t, t^{k}\right) \cdot\left(S^{-1}\right)^{k l} \cdot C\left(x^{l}, x^{\prime}, t^{l}, t^{\prime}\right)
$$

\section{References}

Alsdorf, D., Han S.-C., Bates P. \& Melack J., 2010. Seasonal water storage on the Amazon floodplain measured from satellites, Remote Sensing of Environment, 111, 2448-2456.

Bonnet M.-P., Barroux G., Martinez J.-M., Seyler F., Moreira-Turcq P., Cochonneau G., Melack J.M., Boaventura G., Maurice-Bourgoin L., León J.G., Roux E., Calmant S., Kosuth P., Guyot J.-L. \& Seyler P., 2008. Floodplain hydrology in an Amazon floodplain lake (Lago Grande de Curuaí). Journal of Hydrology. 349, 18-30.

Callède J., Cochonneau G., Ronchail J., Alves F.V., Guyot J.L., Guimarães V.S. \& Oliveira E.d. 2010. Les apports en eau de l'Amazone à l'Océan Atlantique. Revue des Sciences de l'Eau, 23(3): 247273.

Calmant S. \& Seyler F., 2006. Continental surface waters from satellite altimetry. Geosciences C.R., $338,1113-1122$.

Dunne T., Mertes L.A.K., Meade R.H., Richey J.E. \& Forsberg B.R., 1998. Exchanges of sediment between the flood plain and channel of the Amazon River in Brazil. GSA Bull. 110 (4), 450- 467.

Espinoza R., Martinez J.M., Guyot J.L., Frazy P., Armijos E., Crave A., Bazán H., Vauchel P., Lavado W., 2012. Integration of Field Measurements and Satellite Observations to Derive River Solid Load in Poorly Gauged Basins. Journal of Hydrology444-445, 221-228.

Espinoza R., Martinez J.M., Le Texier M., Guyot J.L., Fraizy P., Meneses P., Oliveira E. A study of sediment transport in the Madeira River, Brazil, using MODIS remote-sensing images. Journal of South American Earth Sciences. 44, 45-54.

Fekete B.M. \& Vörösmarty C.J., 2007. The current status of global river discharge monitoring and potential new technologies complementing traditional discharge measurements. Proceedings of the PUB Kick-off meeting, vol. 309. IAHS Publication, Brasilia, pp. 129-136.

Filizola N. \& Guyot J.L., 2009. Suspended sediment yields in the Amazon basin: an assessment using the Brazilian national data set. Hydrol. Process., 23, 3207-3215.

Filizola N., Spínola N., Arruda W., Seyler F., Calmant S. \& Silva J., 2009. The Rio Negro and Rio Solimões confluence point - hydrometric observations during the 2006/2007 cycle. River, Coastal and Estuarine Morphodynamics: RCEM 2009 - Vionnet et al. (eds).

Frappart F., Calmant S., Cauhopé M., Seyler F. \& Cazenave, A., 2006. Preliminary results of ENVISAT RA-2-derived water levels validation over the Amazon basin. Rem. Sens. of Env., 100, 252-264. 
Goulding M., Barthem R. \& Ferreira E., 2003. The Smithsonian Atlas of the Amazon. Smithsonian Institution press, Washington.

Guyot J.L., Filizola N. \& Laraque A., 2005. Régime et bilan du flux sédimentaire de l'Amazone à Óbidos (Pará, Brésil) de 1995 à 2003. Proceedings of Sediment Budget symposium held during the Seventh IAHS Scientific Assembly, vol. 291. IAHS Publication, Foz do Iguaçu, pp. 347-354.

Kilham N. \& Roberts D., 2011. Amazon River time series of surface sediment concentration from MODIS. International Journal of Remote Sensing, 32 (10), 2659-2679.

León J.G., Calmant S., Seyler F., Bonnet M.-P., Cauhopé M., Frappart F., Filizola N. \& Fraizy P., 2006. Rating curves and estimation of average water depth at the upper Negro River based on satellite altimeter data and modeled discharges, Journal of Hydrology, 328, 481-496.

Lesack L. F. W. \& Melack J. M., 1995. Flooding hydrology and mixture dynamics of lake water derived from multiple sources in an Amazon floodplain lake, Water Resource Research, 31(2), 329-345.

Mangiarotti S., 2007. Coastal sea level trends from TOPEX-Poseidon satellite altimetry and tide gauge data in the Mediterranean Sea during the 1990s. Geophysical Journal International, 13, 132-144.

Marengo J.A., Tomasella J. \& Uvo C., 1998. Trends in streamflow and rainfall in tropical South America: Amazonia, eastern Brazil, and northwestern Peru. Journal of Geophysical Research, 103 (D2), pp. 1775-1783, doi:10.1029/97JD02551.

Martinez J.-M., Guyot J.L., Filizola N. \& Sondag F., 2009. Increase in suspended sediment discharge of the Amazon River assessed by monitoring network and satellite data. Catena, 79, 257-264.

Martinez J.-M. \& Le Toan T., 2007. Mapping of flood dynamics and spatial distribution of vegetation in the Amazon floodplain using multitemporal SAR data. Remote Sensing of Environment, 108, 209223.

Maurice-Bourgoin L.M., Bonnet M.-P., Martinez J.-M., Kosuth P., Cochonneau G., Moreira-Turcq P., Guyot J.-L., Vauchel P., Filizola N. \& Seyler P. 2007. Temporal dynamics of water and sediment exchanges between the Curuai floodplain and the Amazon River, Brazil. Journal of Hydrology. 335, 140-156.

Meade R.H., 1994. Suspended sediments of the modern Amazon and Orinoco rivers, Quaternary International, 21, 29-39.

Melack, J. \& L. Hess (2010), Remote sensing of the distribution and extent of wetlands in the Amazon basin, in Amazonian floodplain forests: Ecophysiology, biodiversity and sustainable management, edited by W. J. Junk and M. Piedade, Ecological Studies Springer.

Melack, J.M., Hess, L.L., Gastil, M., Forsberg, B.R., Hamilton, S.K., Lima, I.B.T., Novo, E.M.L.M., 2004. Regionalization of methane emissions in the Amazon basin with microwave remote sensing. Global Change Biology 10, 530-544.

Mertes, L.A.K., 1994. Rates of floodplain sedimentation on the central Amazon River. Geology 22, 171174.

Mertes L.A.K., Daniel D.L., Melack J.M., Nelson B., Martinelli A. \& Forsberg B.R., 1995. Spatial patterns of hydrology, geomorphology, and vegetation on the floodplain of the Amazon River in Brazil from a remote sensing perspective, Geomorphology, 13, 215-232.

Molinier M., Guyot J.-L., Oliveira E. \& Guimaraes V., 1996. Les regimes hydrologiques de l'Amazone et de ses affluents, AlHS, 238, 209-222.

Moreira-Turcq, P., Jouanneau J.M., Turcq B., Seyler P., O. Weber O. \& Guyot J.L., 2004. Carbon sedimentation at Lago Grande de Curuai, a floodplain lake in the low Amazon region: insights into sedimentation rates, Palaeogeography, Palaeoclimatology, Palaeoecology, 214, 27-40.

Nobre P, Malagutti M., Urbano D.F., de Almeida R.A.F. \& Giarolla E., 2009. Amazon deforestation and climate change in a coupled model simulation. Journal of Climate, 22(21): 5686-5697.

ORE HYBAM. The Environmental Research Observatory (ORE) HYBAM (Geodynamical, hydrological and biogeochemical control of erosion/alteration and material transport in the Amazon basin) operates since 2003. http://www.ore-hybam.org. 
Richey, J., Mertes, A., Dunne, T., Victoria, R., Forsberg, B., Tancredi, A. \& Oliveira, E. 1989. Sources and routing of the Amazon River flood wave. Global Biochemical Cycles. 3(3): 191-204.

Richey J.E., Meade R.H., Salati E., Devol A.H., Nordin C.F. \& Santos U. M., 1986. Water Discharge and Suspended Sediment Concentrations in the Amazon River: 1982-1984, Water Resources Research, 22(5), $756-764$.

Santos da Silva, J., S. Calmant, F. Seyler, O. Corrêa Rotunno Filho, G. Cochonneau \& W. J. Mansur (2010), Water levels in the Amazon basin derived from the ERS 2 and ENVISAT radar altimetry missions, Remote Sensing of Environment, 114, 2160-2180.

Sioli H., 1984. The Amazon and its main affluents. In: H. Sioli (Ed.), The Amazon, Limnology and Landscape Ecology of a Mighty Tropical River and Its Basin, Monogr. Biol., 56, Dr. W. Junk, Kluwer Acad., Norwell, MA, USA, 1984, pp. 127-165.

Tarantola A. \& Valette B. 1982. Generalized nonlinear inverse problems solved using the least squares criterion. Rev. of Geophys. and Space Physics. 20(2), 219-232.

Wilson M., Bates P., Alsdorf D., Forsberg B., Horritt M., Melack J., Frappart F. \& Famiglietti J., 2007. Modeling large-scale inundation of Amazonian seasonally flooded wetlands, Geophysical Research Letters, 34(15), L15404.

Zakharova E. A., Kouraev A. V., Cazenave A. \& Seyler F., (2006). Amazon River discharge estimated from TOPEX/Poseidon altimetry. Geosciences Comptes Rendus (French Academy of sciences). 338 (3): 188-196 FEB 2006. 


\section{Table caption}

TABLE 1: Satellite $(S)$ and Field $(F)$ stations coordinates, position $\left(d_{i}\right.$ in $\mathrm{km}$ ) along reach $i$ (see Figure 1$)$, periods covered, and time sampling.

TABLE 2: List of the parameters used in the paper: description, notation, values or range of values and units of measurements.

TABLE 3: Basic statistics on the discharge and SSC series at Óbidos, Manacapuru and Borba stations, before and after the intra-annual year is removed.

TABLE 4: Maximum correlations obtained for discharge and for SSC between Manacapuru and delayed Óbidos stations for various filtering bands; associated time lags and time lag ranges (in day), propagation velocities and associated ranges (in $\mathrm{m}^{-\mathrm{s}^{-1}}$ ), decorrelation distances $\Delta_{x}$ (in $\mathrm{km}$ ).

TABLE 5: Maximum correlations obtained for discharge and for SSC between Borba and delayed Óbidos stations for various filtering bands; associated time lags and time lag ranges (in day), propagation velocities and associated ranges (in $\mathrm{m}^{-\mathrm{s}^{-1}}$ ), decorrelation distances $\Delta_{x}$ (in $\mathrm{km}$ ). To perform these analyses, Manacapuru's discharge delayed of a 10 days lag was removed from Óbidos' discharge

TABLE 6: Parameterization used in the GLS method for estimating the discharge $\hat{\varphi}(x, t)$ and the SSC $\hat{\rho}(x, t)$ at each reach.

TABLE 7: Autodecorrelation times (in day) for both discharge and SSC series at Óbidos, Manacapuru and Borba stations. The propagation timescale being close to weekly, seasonal variability should be filtered. Two filters are used $(<100$ days and $>100$ days respectively) that clearly illustrate this timescale behaviour.

TABLE 8: Experiments description and results of the three estimators: $J_{\text {Itacoatiara }}^{S}, J_{\text {Obidos }}^{S}$ and $J_{\text {Obidos }}^{F}$.

TABLE 9: Synthetic presentation of previously published results of deposition rates, quantity of suspended sediments trapped and accumulation rates obtained for various areas at different space and time scales. Values in bold type are directly taken from the references, others are deduced for comparison. 


\section{Tables}

Table 1:

\begin{tabular}{|c|c|c|c|c|c|c|c|c|c|c|}
\hline \multirow[t]{2}{*}{ Station } & \multirow{2}{*}{$\begin{array}{l}\text { Lat. } \\
\left({ }^{\circ} \mathrm{N}\right) \\
\end{array}$} & \multirow{2}{*}{$\begin{array}{l}\text { Long. } \\
\left({ }^{\circ} \mathrm{W}\right)\end{array}$} & \multirow[t]{2}{*}{ reach $i$} & \multirow{2}{*}{$\begin{array}{l}d_{i} \\
(\mathrm{~km})\end{array}$} & \multicolumn{3}{|c|}{ Water Flux } & \multicolumn{3}{|c|}{ SSC (MODIS) } \\
\hline & & & & & sampling & Period & Type & sampling & Period & Type \\
\hline \multirow[t]{2}{*}{ Óbidos } & $1^{\circ} 56^{\prime} 50^{\prime \prime}$ & $55^{\circ} 30^{\prime} 40^{\prime \prime}$ & 1 & 100 & 1-day & $1995-2007$ & $\mathrm{~F}$ & 8-day & $2000-2007$ & $S$ \\
\hline & & & & & - & - & - & 10-day & $2000-2004$ & $F$ \\
\hline Itacoatiara & & & 1 & 490 & - & - & - & 8-day & 2000-2007 & $S$ \\
\hline \multirow[t]{2}{*}{ Manacapuru } & $3^{\circ} 20^{\prime} 43^{\prime \prime}$ & $60^{\circ} 33^{\prime} 12^{\prime \prime}$ & 6 & 92 & 1-day & $1995-2007$ & $\mathrm{~F}$ & 8-day & $2000-2007$ & $S$ \\
\hline & & & & & - & - & - & 10-day & $2000-2003$ & $F$ \\
\hline \multirow[t]{2}{*}{ Borba } & $4^{\circ} 53^{\prime} 50^{\prime \prime}$ & $60^{\circ} 01^{\prime} 31^{\prime \prime}$ & 2 & 160 & 1-day & $1995-2007$ & $\mathrm{~F}$ & 8-day & $2000-2007$ & $S$ \\
\hline & & & & & - & - & - & 10-day & $2000-2004$ & $\mathrm{~F}$ \\
\hline
\end{tabular}


Table 2:

\begin{tabular}{|c|c|c|c|}
\hline Parameter & Notation & Value or Range & Unit \\
\hline \multirow[t]{2}{*}{ Fluvial reach } & $i$ & {$[1 ; 2 ; 3 ; 6 ; 7]$} & no unit \\
\hline & binary & {$[1 ; 10 ; 11 ; 110 ; 111]$} & - \\
\hline Amplification coefficient of Flow & $\alpha_{\varphi}$ & $2.10^{-5}$ & $\mathrm{~km}^{-1}$ \\
\hline Decorrelation time (<100 days) & $\Delta t$ & 5 & day \\
\hline \multirow[t]{2}{*}{ Decorrelation distance (<100 days) } & $\Delta_{r}$ & 500 & $\mathrm{~km}$ \\
\hline & $\sigma^{\circ}$ & Variable & $m^{3} \cdot s^{-1}$ \\
\hline Decorrelation time (>100day) & $\Delta_{t}$ & 5 & day \\
\hline \multirow[t]{2}{*}{ Decorrelation distance (>100day) } & $\Delta_{r}$ & 500 & $\mathrm{~km}$ \\
\hline & $\sigma$ & $\sigma_{\text {clim }}(t)$ & $m^{3} \cdot s^{-1}$ \\
\hline Time step & $\delta t$ & 5 & day \\
\hline Space step & $\delta r$ & 20 & $\mathrm{~km}$ \\
\hline Distance along reach $i$ & $d_{i}$ & Variable & $\mathrm{km}$ \\
\hline Total distance to Santarém & $d$ & Variable & $\mathrm{km}$ \\
\hline Reach length & $D_{i}$ & {$[570 ; 300 ; 135 ; 200 ; 100]$} & $\mathrm{km}$ \\
\hline Borba along reach position & $d_{\text {Borba }}$ & $d_{2}=160$ & $\mathrm{~km}$ \\
\hline Itacoatirata along reach position & $d_{\text {ltacoatiara }}$ & $d_{1}=490$ & $\mathrm{~km}$ \\
\hline Óbidos along reach position & dóbidos & $d_{1}=100$ & $\mathrm{~km}$ \\
\hline Manacapuru along reach position & $d_{\text {Manacapuru }}$ & $d_{6}=92$ & $\mathrm{~km}$ \\
\hline Santarém along reach position & $d_{\text {Santarem }}$ & $d_{1}=0$ & $\mathrm{~km}$ \\
\hline
\end{tabular}


Table 3:

\begin{tabular}{|c|c|c|c|c|c|c|c|c|}
\hline \multirow{3}{*}{$\begin{array}{l}\text { Station } \\
\text { Climatology } \\
\text { removed: }\end{array}$} & \multicolumn{4}{|c|}{ Discharge $\left(\mathrm{m}^{3} \mathrm{~s}^{-1}\right)$ period $1995-2008$} & \multicolumn{4}{|c|}{ SSC $\left(\mathrm{g} \cdot \mathrm{m}^{-3}\right)$ period $2000-2007$} \\
\hline & \multicolumn{2}{|l|}{ Average } & \multicolumn{2}{|l|}{ Std } & \multicolumn{2}{|c|}{ Average } & \multicolumn{2}{|l|}{ Std } \\
\hline & No & Yes & No & Yes & No & Yes & No & Yes \\
\hline Óbidos & 171810 & 0 & 53220 & 16350 & 149 & 0 & 95 & 49 \\
\hline Manacapuru & 102340 & 0 & 30340 & 11530 & 209 & 0 & 76 & 40 \\
\hline Borba & 26880 & 0 & 18250 & 4880 & 369 & 0 & 342 & 189 \\
\hline
\end{tabular}


Table 4:

\begin{tabular}{|c|c|c|c|c|c|c|}
\hline Filter band & $\begin{array}{l}\text { Maximum } \\
\text { correlation }\end{array}$ & $\begin{array}{l}\text { Time } \\
\text { lag }\end{array}$ & $\begin{array}{l}\text { Time lag } \\
\text { range }\end{array}$ & Velocity & $\begin{array}{l}\text { Velocity } \\
\text { range }\end{array}$ & $\Delta x$ \\
\hline \multicolumn{7}{|c|}{ Discharge delay analysis between Manacapuru and Óbidos $(d=562 \mathrm{~km})$} \\
\hline day $^{-1}$ & n.u. & day & day & m.s. & m.s. & $\mathrm{km}$ \\
\hline [1-50] & 0.2851 & 6.4 & {$[3-10.5]$} & 1.02 & {$[0.6-2.2]$} & 352 \\
\hline$[1-100]$ & 0.5372 & 9.5 & {$[5.5-13.5]$} & 0.68 & {$[0.5-1.2]$} & 506 \\
\hline$[50-100]$ & 0.6372 & 10.6 & {$[6.5-14.5]$} & 0.61 & {$[0.4-1.0]$} & 595 \\
\hline$[50-150]$ & 0.7172 & 10.8 & {$[6-15]$} & 0.60 & {$[0.4-1.1]$} & 693 \\
\hline$[100-200]$ & 0.8029 & 9.8 & {$[4.5-15]$} & 0.66 & {$[0.4-1.4]$} & 841 \\
\hline$[100-400]$ & 0.7592 & 6.4 & {$[0-14]$} & 1.02 & $>0.5$ & 759 \\
\hline$[100-2000]$ & 0.7949 & 6.5 & {$[0-20]$} & 1.00 & $>0.3$ & 818 \\
\hline \multicolumn{7}{|c|}{ SSC delay analysis between Manacapuru and Óbidos $(d=562 \mathrm{~km})$} \\
\hline$[50-100]$ & 0.0721 & 13.7 & {$[0-27]$} & 0.47 & $>0.2$ & 244 \\
\hline$[50-150]$ & 0.0776 & 7.9 & {$[0-24]$} & 0.82 & $>0.3$ & 250 \\
\hline$[100-200]$ & 0.2857 & 3.1 & {$[0-21]$} & 2.10 & $>0.3$ & 357 \\
\hline$[100-400]$ & 0.4371 & 11.8 & {$[0-35]$} & 0.55 & $>0.2$ & 439 \\
\hline$[100-2000]$ & 0.5099 & 8.6 & {$[0-30]$} & 0.76 & $>0.2$ & 484 \\
\hline
\end{tabular}

Values in bold type correspond to the values used for the analyses. 
Table 5:

\begin{tabular}{lllllll}
\hline Filter band & $\begin{array}{l}\text { Maximum } \\
\text { correlation }\end{array}$ & Time lag & $\begin{array}{l}\text { Time lag } \\
\text { range }\end{array}$ & Velocity & $\begin{array}{l}\text { Velocity } \\
\text { range }\end{array}$ & $\Delta_{x}$ \\
\hline \multicolumn{7}{c}{ Discharge delay analysis between Borba and Óbidos $(d=630 \mathrm{~km})$} \\
\hline day- $^{-1}$ & n.u. & Day & day & ${\mathrm{m} . \mathrm{s}^{-1}}^{-1}$ & $\mathrm{m.s}^{-1}$ & $\mathrm{~km}$ \\
\hline$[1-50]$ & 0.0512 & 20 & {$[4-25]$} & 0.33 & {$[0.3-1.8]$} & 257 \\
{$[1-100]$} & 0.1058 & 20.6 & {$[13-28]$} & 0.32 & {$[0.3-0.6]$} & 300 \\
{$[50-100]$} & 0.1494 & 21.8 & {$[14-30]$} & 0.30 & {$[0.2-0.5]$} & 323 \\
{$[50-150]$} & 0.2028 & 21.9 & {$[13-28]$} & 0.30 & {$[0.3-0.6]$} & 351 \\
{$[100-200]$} & 0.2692 & 43.3 & {$[28-58]$} & 0.15 & {$[0.1-0.3]$} & 389 \\
\hline \multicolumn{7}{c}{ SSC delay analysis between Borba and Óbidos $(d=630 \mathrm{~km})$} \\
\hline$[1-100]$ & 0.0860 & 15.3 & {$[3-27]$} & 0.43 & {$[0.3-2.4]$} & 287 \\
{$[50-100]$} & 0.3182 & 13.2 & {$[4-22]$} & 0.49 & {$[0.3-1.8]$} & 417 \\
{$[50-150]$} & 0.3410 & 13.7 & {$[4-23]$} & 0.47 & {$[0.3-1.8]$} & 429 \\
{$[100-200]$} & 0.5494 & 8.1 & {$[0-19]$} & 0.80 & $>0.4$ & 576 \\
{$[100-400]$} & 0.6788 & 8.6 & {$[0-20]$} & 0.76 & $>0.4$ & 717 \\
{$[100-2000]$} & 0.6489 & 6.0 & {$[0-19]$} & 1.08 & $>0.4$ & 679 \\
\hline
\end{tabular}


Table 6:

\begin{tabular}{|c|c|c|c|c|}
\hline \multicolumn{5}{|c|}{ Discharge inversion } \\
\hline \multirow[t]{2}{*}{ Parameter } & \multicolumn{4}{|l|}{ Reach } \\
\hline & 1 & 2 & 3 & 6 \\
\hline$c\left(\mathrm{~m} \mathrm{~s}^{-1}\right)$ & 0.6 & 0.5 & 0.6 & 0.6 \\
\hline$\Delta_{t}($ day $)$ & 8 & 6 & 8 & 7 \\
\hline$\Delta_{r}(\mathrm{~km})$ & 690 & 350 & 690 & 690 \\
\hline$\sigma\left(m^{3} s^{-1}\right)$ & $\sigma_{\text {clim }}(t)$ & $\sigma_{\text {clim }}(t)$ & $\sigma_{\text {clim }}(t)$ & $\sigma_{\text {clim }}(t)$ \\
\hline$\sigma_{0}\left(m^{3} s^{-1}\right)$ & 5000 & 4500 & 6000 & 7000 \\
\hline \multicolumn{5}{|c|}{ Suspended sediment flow inversion } \\
\hline \multirow[t]{2}{*}{ Parameter } & \multicolumn{4}{|l|}{ Reach } \\
\hline & 1 & 2 & 3 & 6 \\
\hline$c\left(\mathrm{~m} \mathrm{~s}^{-1}\right)$ & 0.6 & 0.5 & 0.6 & 0.6 \\
\hline$\Delta_{t}($ day $)$ & 3 & 4 & 3 & 3 \\
\hline$\Delta_{r}(\mathrm{~km})$ & $430^{*}$ & 430 & 250 & 250 \\
\hline$\sigma\left(m^{3} s^{-1}\right)$ & $\sigma_{\text {clim }}(t)$ & $\sigma_{\text {clim }}(t)$ & $\sigma_{\text {clim }}(t)$ & $\sigma_{\text {clim }}(t)$ \\
\hline$\sigma_{0}\left(m^{3} \mathrm{~s}^{-1}\right)$ & $50^{*}$ & 50 & 30 & 50 \\
\hline
\end{tabular}


Table 7:

\begin{tabular}{|c|c|c|c|c|c|c|c|c|}
\hline \multirow{3}{*}{$\begin{array}{l}\text { Station } \\
\text { Climatology } \\
\text { removed }\end{array}$} & \multicolumn{8}{|c|}{ Decorrelation time (day) } \\
\hline & \multicolumn{4}{|c|}{ Discharge } & \multicolumn{4}{|c|}{ SSC } \\
\hline & No & Yes & Yes & Yes & No & Yes & Yes & Yes \\
\hline Filter & No & No & $<100$ & $>100$ & No & No & $<100$ & $>100$ \\
\hline Óbidos & 44 & 70 & 8 & 71 & 35 & 4 & 3 & 31 \\
\hline Manacapuru & 41 & 45 & 7 & 45 & 30 & 11 & 3 & 32 \\
\hline Borba & 44 & 62 & 6 & 169 & 30 & 6 & 4 & 23 \\
\hline
\end{tabular}


Table 8:

\begin{tabular}{|c|c|c|c|c|c|c|c|}
\hline \multirow[t]{2}{*}{ Experiment } & \multicolumn{4}{|c|}{ Data used in the inversion } & \multicolumn{3}{|c|}{ Cost (mg.l-1) } \\
\hline & Manacapuru & Borba & Itacoatiara & Óbidos & $J \mathrm{~S}_{\text {Itacoatiara }}$ & $J \mathrm{~S}_{\text {Óbidos }}$ & $J_{\text {Óbidos }}$ \\
\hline a priori & - & - & - & - & 95. & 58. & 53. \\
\hline $1 \mathrm{a}$ & Sat & Sat & - & - & 61. & 50. & 43. \\
\hline $1 b$ & Field & Field & - & - & 68. & 53. & 43. \\
\hline $1 c$ & Sat + Field & Sat + Field & - & - & 63. & 50. & 43. \\
\hline 2 & Sat & Sat & Sat & - & 32. & 52. & 50. \\
\hline $3 a$ & Sat & Sat & Sat & Sat & 28. & 16. & 52. \\
\hline $3 b$ & Sat + Field & Sat + Field & Sat & Sat + Field & 28. & 22. & 31. \\
\hline
\end{tabular}


Table 9:

\begin{tabular}{|c|c|c|c|c|c|c|c|c|c|c|}
\hline \multirow[t]{3}{*}{ Source } & \multicolumn{5}{|l|}{ Area of study } & \multicolumn{5}{|l|}{ Estimates } \\
\hline & Zone & $\begin{array}{l}\text { Surface } \\
(\max )\end{array}$ & Reach length & $\begin{array}{c}\text { Time } \\
\text { window }\end{array}$ & $\begin{array}{l}\text { Reference } \\
\text { flux }\end{array}$ & $\begin{array}{l}\text { Quantity } \\
\text { trapped }\end{array}$ & $\begin{array}{l}\text { Deposition } \\
\text { rates }\end{array}$ & & & $\begin{array}{c}\text { Accumulation } \\
\text { rate }\end{array}$ \\
\hline & & $\mathrm{km}^{2}$ & $\mathrm{~km}$ & yr & Mt.yr-1 & Mt. yr-1 & t.km-2.yr-1 & Mt.km-1.yr-1 & in $\%$ & $m m \cdot y r^{-1}$ \\
\hline Mertes $(1994)^{\dagger}$ & $\begin{array}{rr}\text { Solimões River }(a)^{\ddagger} \\
\\
(b)^{\ddagger}\end{array}$ & $510^{3}$ & 200 & $3^{\dagger}$ & 700 & $\begin{array}{c}22 \\
220-360\end{array}$ & $\begin{array}{c}410^{3} \\
4.4-7.210^{4}\end{array}$ & $\begin{array}{c}0.11 \ddagger \\
1.1-1.8^{\ddagger}\end{array}$ & $\begin{array}{c}3 \\
31-51\end{array}$ & $\begin{array}{c}12.3 \\
135-221\end{array}$ \\
\hline Dunne et al. (1998) - & São Jose de A.-Obidos & 12160 & 503 & $10-16$ & 1239 & 95 & $7.810^{3}$ & 0.19 & 7.7 & 24.0 \\
\hline Filizola \& Guyot (2009) & Whole Amazon River & $910^{4}$ & 2010 & $>30$ & 1100 * & $100^{* *}$ & $>10^{3}$ & 0.05 & 9 & $5-6$ \\
\hline Moreira-Turcq et al. (2004) & Curuaí floodplain & 2500 & 120 & $\sim 100$ & 1200 & $35-110$ & $1.4-4.410^{4}$ & $0.29-0.91$ & 3-9 & 4.2-13.4 \\
\hline Maurice-Bourgoin et al. (2007) & Curuaí floodplain & 2500 & 120 & 3 & 964 & 1.3 & 517 & $<10^{-2}$ & 0.07 & 1.6 \\
\hline this work & Itacoatiara-Óbidos & 14230 & 390 & 8 & 810 & 125 & $8.810^{3}$ & 0.32 & 15.4 & 27.1 \\
\hline
\end{tabular}

Values in bold type are directly taken from the quoted references, others are deduced for comparison.

- When non available, estimates of accumulation rates are derived using a density of $1.3 \mathrm{~g} \cdot \mathrm{m}^{-3}$ and a porosity of $75 \%$ (Maurice-Bourgoin et al. 2007). The same density and porosity are used to deduce, reversely, the quantity trapped and deposition rates from the accumulation rates published by Moreira-Turcq et al. (2004).

† These estimates are based on measurements of three individual floods and not a complete cycle.

‡ Two cases are presented here. The first one (a) is based on the lower values of deposition rates $\left(0.3 \mathrm{t}_{\text {.day }}{ }^{-1} \cdot \mathrm{m}^{-1}\right)$ provided in Mertes (1994) corresponding to measurements made $100 \mathrm{~m}$ in the floodplains appear more relevant for the present comparison. The second one $(b)$ is based on the larger ones $\left(3-5 \mathrm{t}^{-} \cdot \mathrm{tat}^{-1} \cdot \mathrm{m}^{-1}\right)$ corresponding to measurements made on the bordering part of floodplains.

- Values are deduced from sediment deposition presented in Dunne et al. (1998) (see Figure 4) based on the estimates of deposition rates of 0.16 and 0.22 Mt.km-1. $\mathrm{yr}^{-1}$ performed between stations São Jose de Amatarí, Paurá \& Óbidos.

* This value account for the Andean contribution (1000 Mt.yr-1) plus a lower contribution (100 Mt.yr-1) from the shield areas (Filizola \& Guyot 2009).

** Value estimated between Manacapuru and Óbidos. 


\section{Figure Caption}

FIGURE 1: Map and Schematic representation of the domain considered in the study: between Manacapuru and Óbidos along the Amazon River, from Borba to the junction with the Amazon River along the Madeira River, and the junction of the Negro River with the Amazon River. Data are available at Manacapuru, Borba, Itacoatiara and Óbidos. Santarém is used as a reference point for the distance along reach 1. The notation used for the reaches is explained in appendix A.1.

FIGURE 2: Discharge (in $\mathrm{m}^{3} \cdot \mathrm{s}^{-1}$ ) time series (dark line) estimated at Borba (top panel), Manacapuru (central panel) and Óbidos (bottom panel), between 2000 and 2008. The associated error is represented by the dashed lines.

FIGURE 3: Suspended Sediment Concentration (in $\mathrm{mg.l}^{-1}$ ) time series estimated from satellite data (dark line) or measured on field (dots) at Borba (top panel), Manacapuru (2nd panel), Itacoatiara (3rd panel) and Óbidos (bottom panel) between 2000 and 2008. Error associated with satellite data is represented by the dashed lines.

FIGURE 4: Intra-annual Discharge time series (top panels) in $\mathrm{m}^{3} . \mathrm{s}^{-1}$ as a function of Day Of Year (DOY) at Óbidos (first column), Manacapuru (second column) and Borba (third column). The clouds of circles correspond to the daily individual measurements (between 1995 and 2008), the plain line denotes the intra-annual averaged year and the dashed lines denote the one sigma dispersion (standard deviation) from the average line. Middle panels show the distribution of the data during 1995-2008. The bottom panels show the distribution after removed the intra-annual averaged year.

FIGURE 5: intra-annual time series of the Suspended Sediment Concentration (top panels) in mg.l-1 (estimated from satellite data) as a function of Day Of Year (DOY) at Óbidos (first column), Manacapuru (second column) and Borba (third column). The circles represent the 8-day individual measurements (between 2000 and 2008), the plain line denotes the intra-annual averaged year and the dashed lines denote the one sigma dispersion from the average line. Middle panels show the distribution of the data during 2000-2008. The bottom panels show the distribution after the intraannual averaged year has been removed.

FIGURE 6: Correlation between the signal of discharge measured at Óbidos and the signal of discharge delayed of time lag $\delta t$ measured at Manacapuru, and expressed as a function of $\delta t$ (in day). The circles denote the computed correlation, the plain line is a polynomial fitting used for a more precise estimate of the delay associated with the maximum correlation. Dashed lines denote the associated error. Seven cases of range of passing filters are considered (see Table 4): [1 - 50], [1 - 100], [50 100], [50 - 150], [100 - 200], [100 - 400] and [100 - 2000] (in day) and noted 1 to 7, respectively. Maximum correlations and corresponding time lags, time lag ranges, propagation velocity and associated ranges corresponding to these various filtering bands are given in Table 4.

FIGURE 7: Output (a posteriori model) of the generalized least square method estimated for the discharge along reach 2 (top panel) and along reaches 6, 3 and 1 successively (bottom panel) during the period 2004-2008. The vertical axis provides the distance to Santarém (in $\mathrm{km}$ ), the horizontal axis refers to time (date in year). The left panels represent the discharge (in $\mathrm{m}^{3} . \mathrm{s}^{-1}$ ), the right panels provide the associated error. Dashed lines indicate the spatial location of stations Óbidos, Itacoatiara, Manacapuru and Borba. 
FIGURE 8: Scatter plots of the SSC (in mg.|-1) estimated from the generalized least square method versus the SSC estimated from MODIS data at Itacoatiara (top panel) and Óbidos (bottom panel). Several experiments are presented corresponding to the a priori model and experiments (1a), (1b), (1c) and (2).

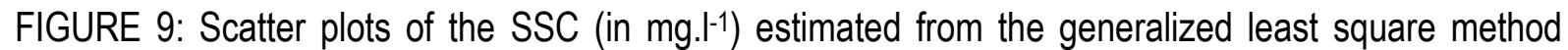
versus the SSC estimated at Óbidos from MODIS data (left panel) and versus the field data observed at Óbidos (right panel). Several experiments are presented corresponding to the a priori model and experiments (1c), (2), (3a) and (3b).

FIGURE 10: Suspended Sediment flux estimated along reach 2 (top panel) and along reaches 6, 3 and 1 successively (bottom panel) during 2000 and 2008. The computation is deduced from Eq. 1, and is based on the discharge shown in figure 7, and on the 'optimal' SSC obtained from the GLS method in experiment (3b). The vertical axis denotes the distance to Santarém (in km), the horizontal axis refers to time (date in year). The left panels give the suspended sediment flux (in $\mathrm{kg} . \mathrm{s}^{-1}$ ), the right panels provide the associated error. Dashed lines indicate the spatial location of stations Óbidos, Itacoatiara, Manacapuru and Borba.

FIGURE 11: Deposition rate (in t.km-1.. $\mathrm{rr}^{-1}$ ) estimated between Itacoatiara and Óbidos (1st panel). Suspended sediment flux estimated at Óbidos (in t.yr-1) plotted together with the percentage of floodplain storage as compared to the suspended sediment flux passing at the Óbidos station ( $2^{\text {nd }}$ panel). 


\section{Figures}

Figure 1 :
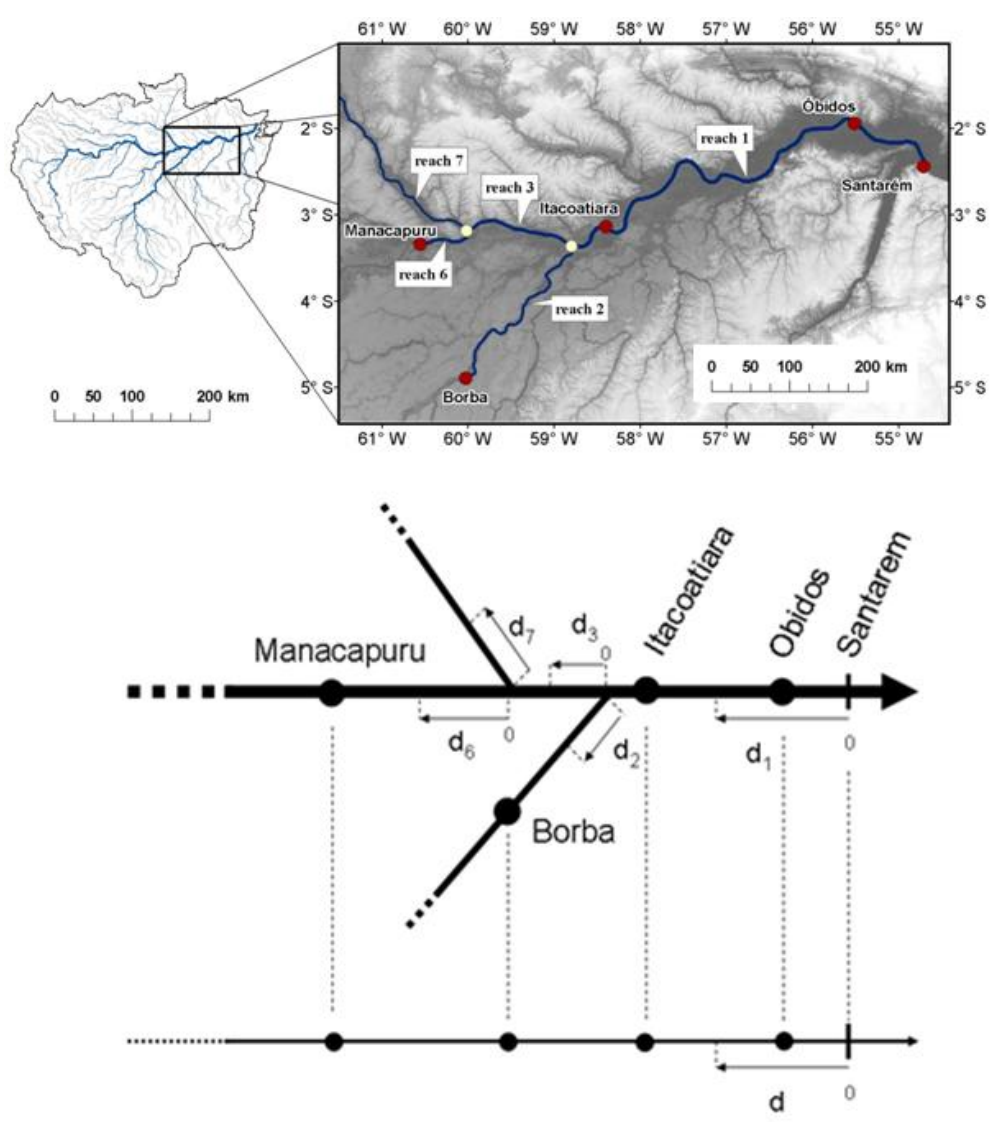
Figure 2:
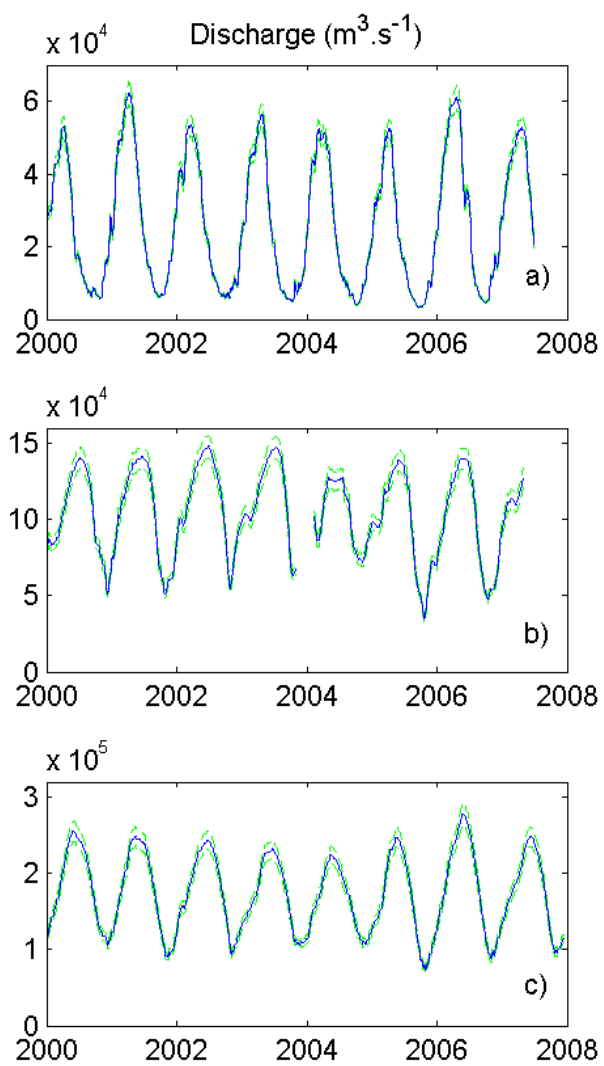
Figure 3:
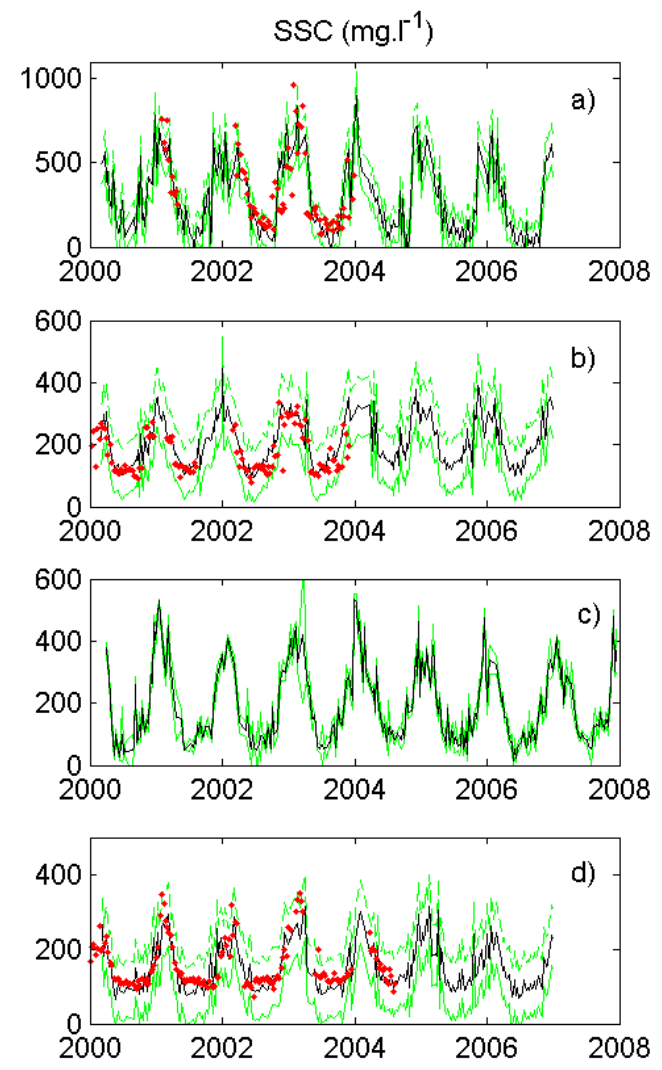
Figure 4:
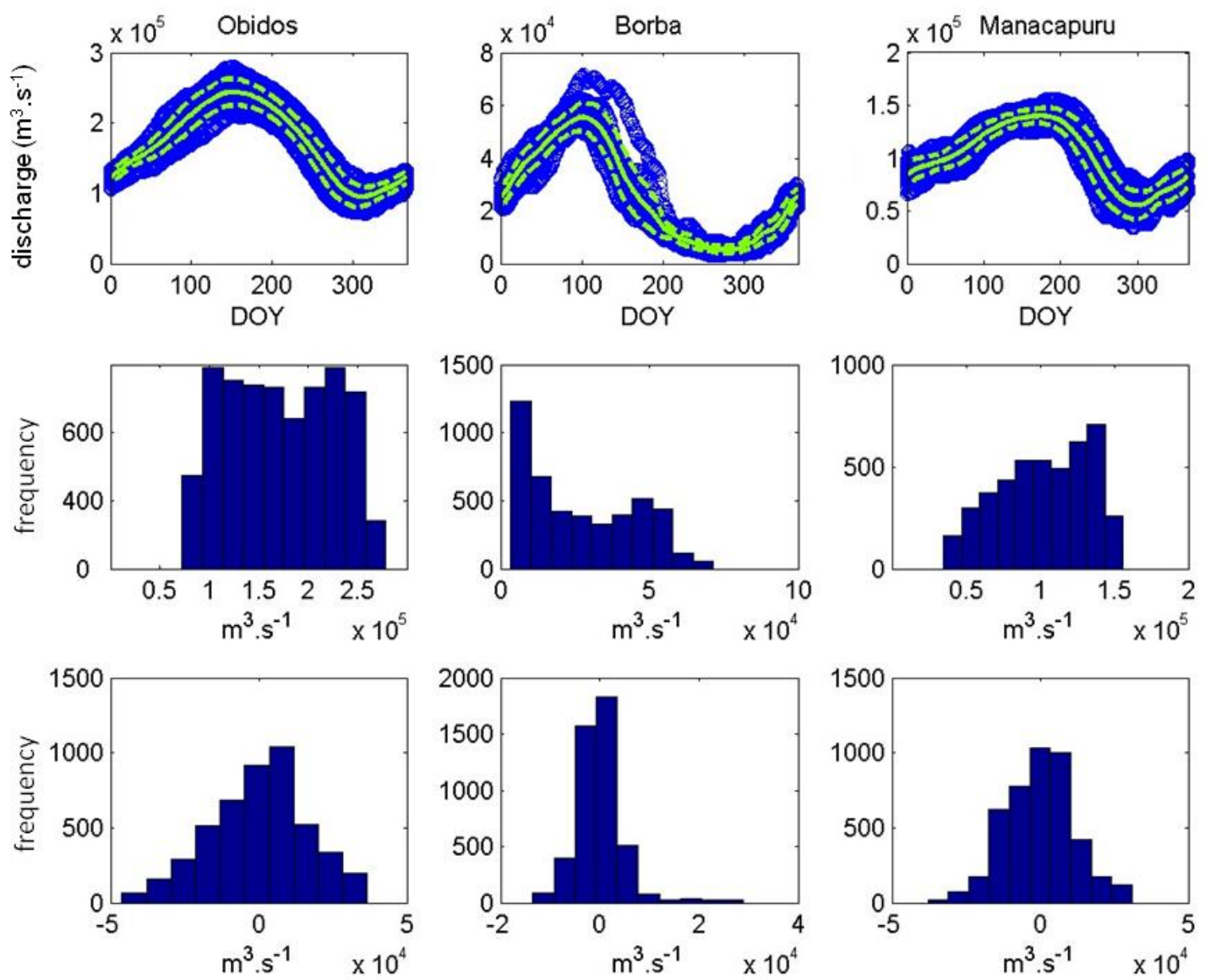
Figure 5:
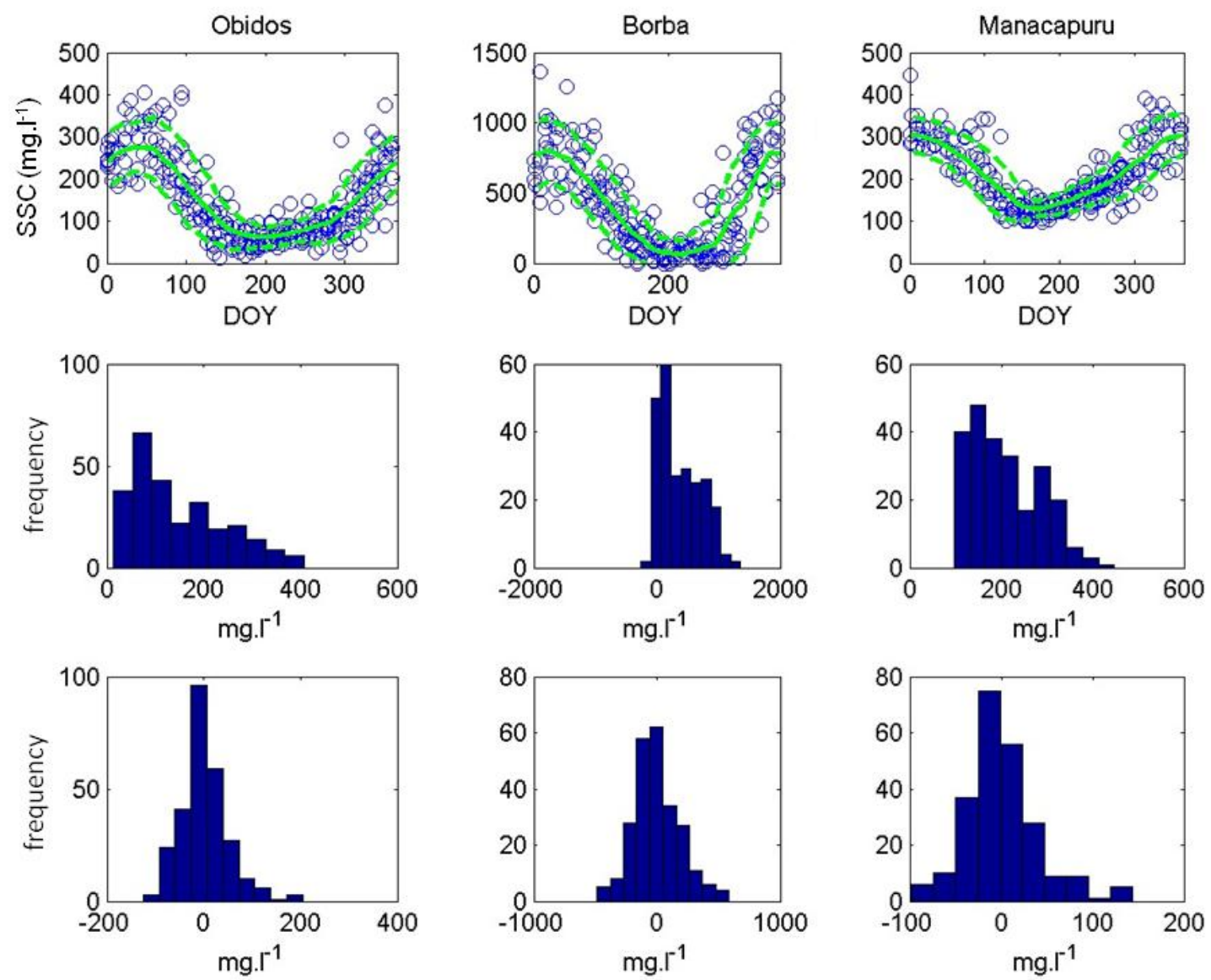
Figure 6:

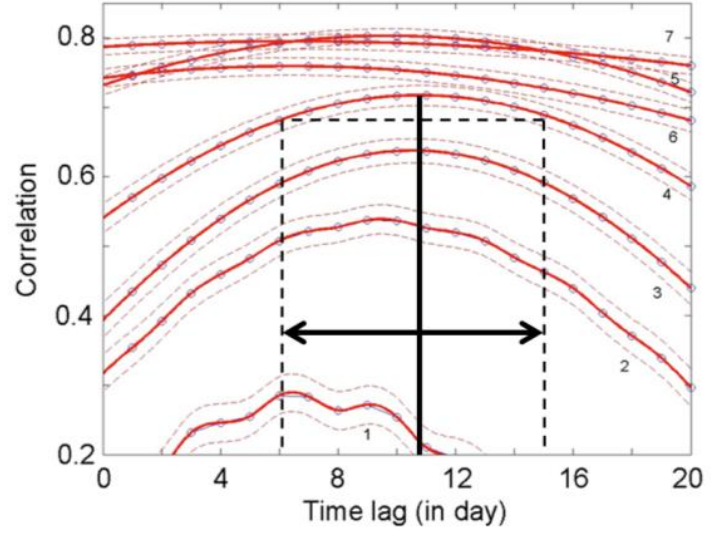


Figure 7:
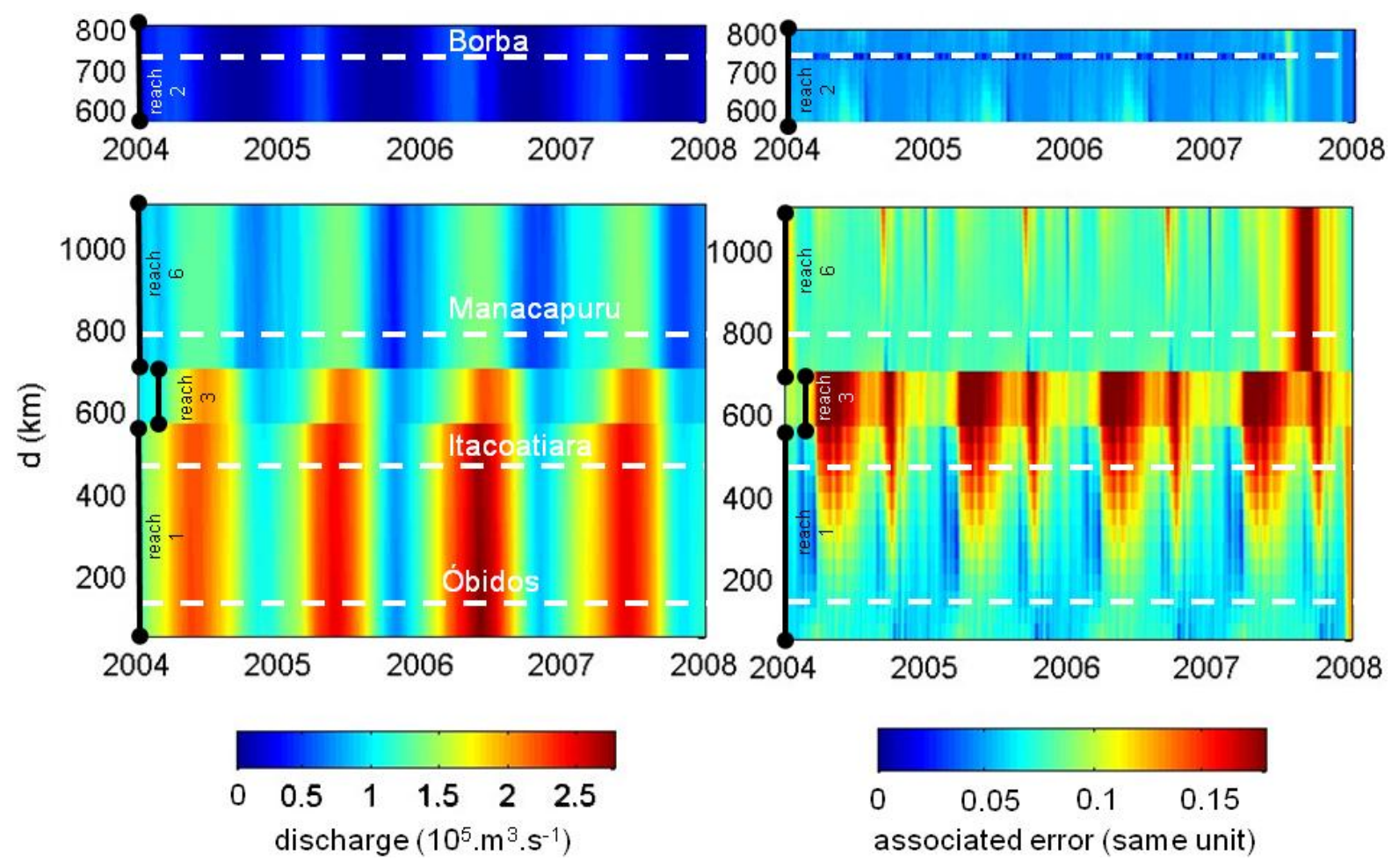

discharge $\left(10^{5} \cdot \mathrm{m}^{3} \cdot \mathrm{s}^{-1}\right)$

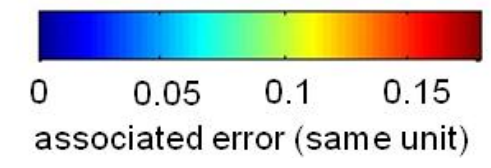


Figure 8:
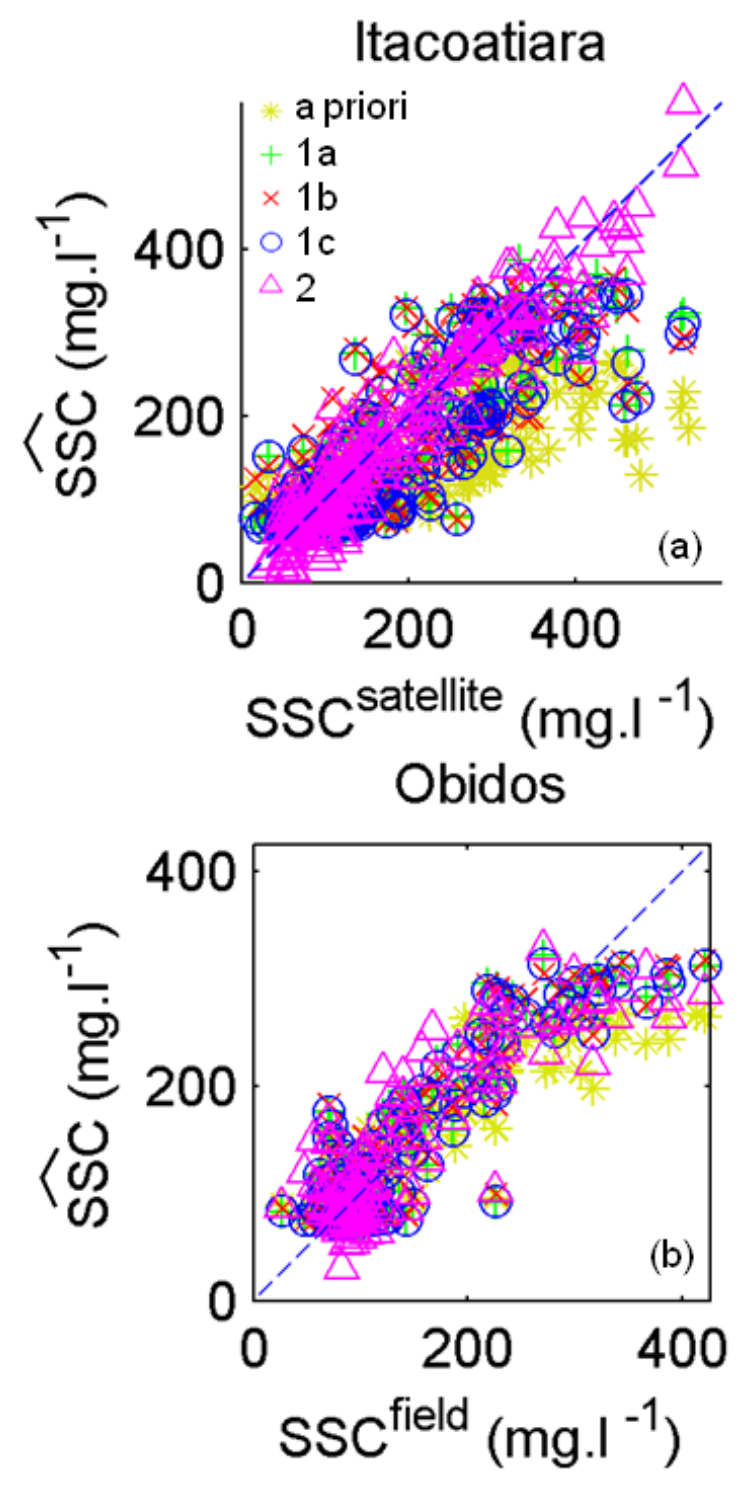
Figure 9:
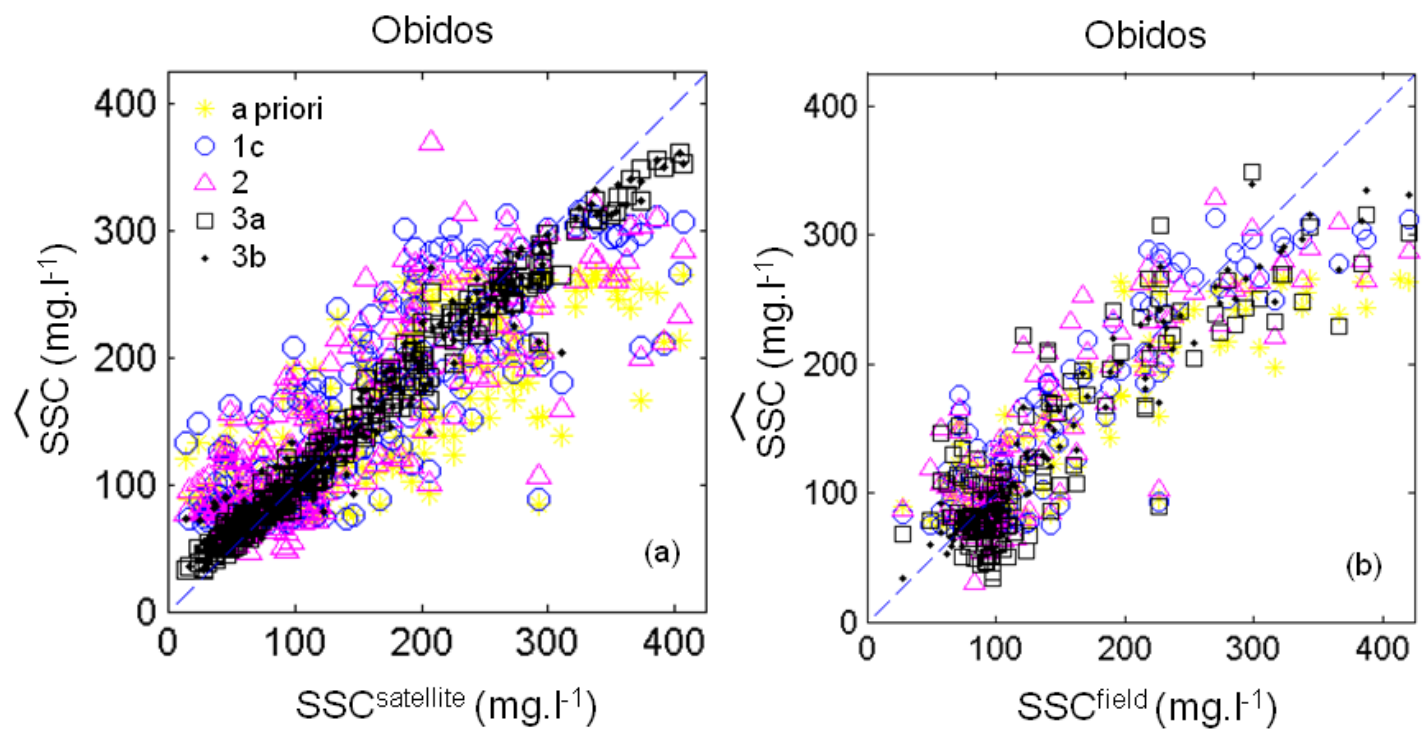
Figure 10:
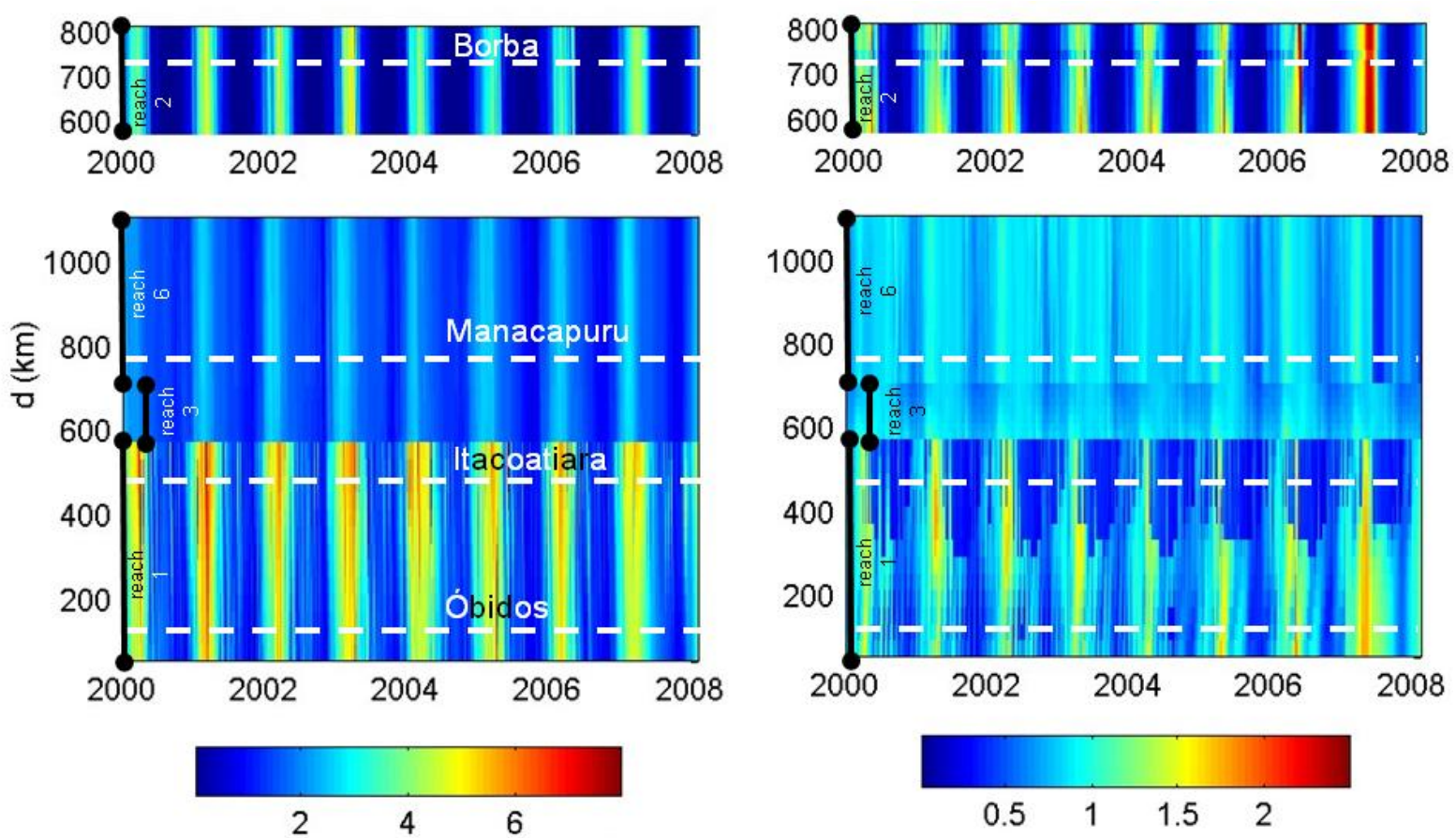

sediment flux $\left(10^{7} \cdot \mathrm{kg} \cdot \mathrm{s}^{-1}\right)$

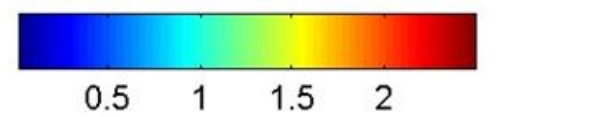

associated error (same unit) 
Figure 11:
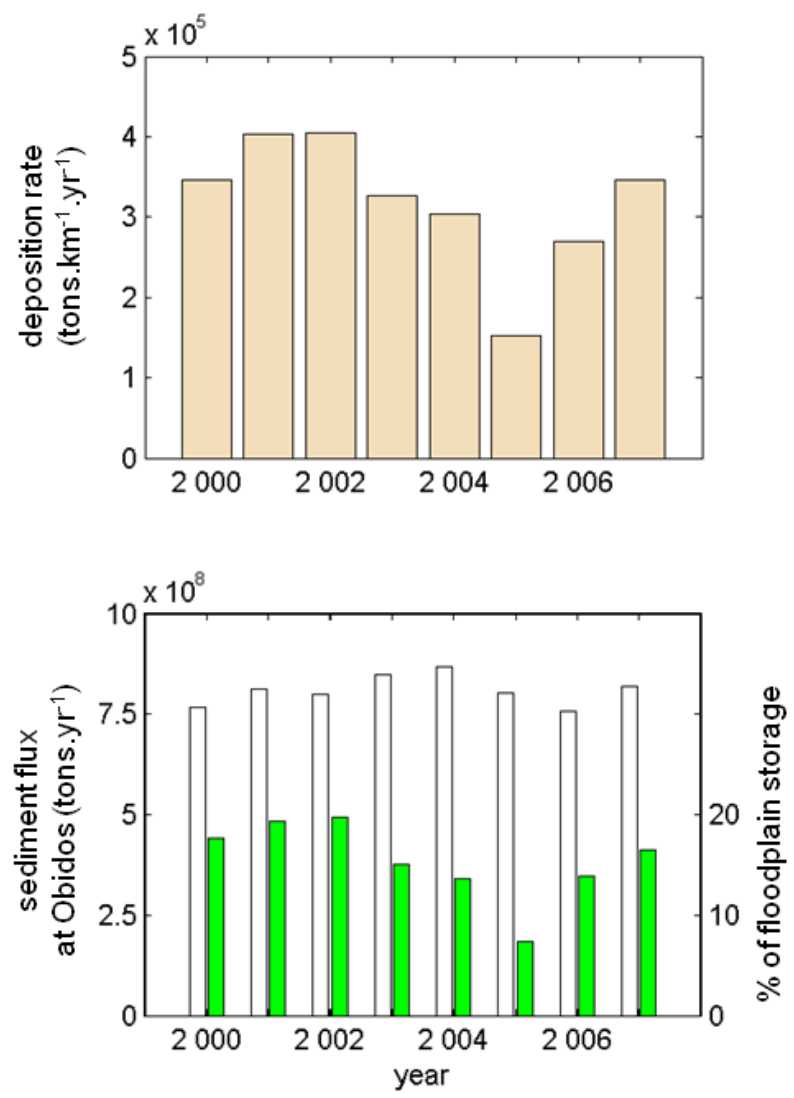